論 文

\title{
各種定格高圧水銀ランプ点灯回路の一高調波分析法
}

\author{
正会員 家 村 道 雄 (熊本工業大学) \\ 正会員 黒 住 正 明 (宮崎工業高等学校) 専門会員 山口 純 - (能本工業大学)
}

\section{Analysis of Harmonic Waves in the Operating Circuit for High-Pressure Mercury Arc Lamps of Various Ratings}

Michio Iemura (Member) (Kumamoto Institute of Technology)

Masayuki Tanaka (Kitakyushu National College of Technology)

Masaaki Kurosumi (Member) (Miyazaki Technological High School)

Junichi Yamaguchi (Fellow Member) (Kumamoto Institute of Technology)

\begin{abstract}
In the operating circuits of high-pressure mercury arc lamps of various ratings, the voltage and current characteristics of the lamps exhibit some analogous properties inherent in their respective characteristics pairs.

In this paper, we first replace the lamp, treated as a circuit element by a equivalent conductance. Then, based on the model constants of the equivalent conductance of the lamp's operating circuit having specified ratings, we obtain from the analogous properties of the lamp's voltage and current characteristics the corresponding model constants of the equivalent conductance for the lamp in operating circuits having various other ratings. This makes possible waveform analysis of the voltage and current characteristics of each circuit element by simulation, which is described in this paper.
\end{abstract}

\section{1. まえがき}

放電ランプ点灯回路の回路解析には理論的な方法と奏験的な方 法がある。

理論的な方法としては，進相形点灯回路について，ランプ電圧 を矩形波の定電圧，または電源電压より位相が進んでいる台形波 独立定電压として電流を求好て, 波形分析子る方法等が発表され ている1),2.また, シミュレーションにより解析古る方法としては, 放電ランプの電気特性を瞬時等価コンダクタンスでモデル化し解 析する方法 ${ }^{3}$, アークプラズマ柱内の電界, アークプラズマ柱の長 さを考慮に入れて解析する方法4等がある。しかし，これらの発表 ではいずれも高調波分析については言及されていない。

半導体応用機器の普及, 或いは放電ランプ等の非線形負荷が増 加し, 電力系統の電压Uずみが拡大し高調波障害が増加しつつあ る今日，より早くて簡単な高調波分析手法が望まれている.

実験的に高調波分析古る場合, 各素子の電圧, 電流の記録を取 ク、計算機で高調波解析する方法，さらに，正確に分析古るには 高精度な高調波分析器を用いる方法がある。

筆者等は高压水銀ランプ点灯回路において，ランプの等価コン ダクタンスのモデル定数を用いてのシミュレーションにより, 各 素子の電圧, 電流が高調波分析できることを示吉.また， $200 \mathrm{~W}$ 以 上の各種定格高圧水銀ランプ点灯回路においては, ランプの電圧, 電流波形はそれぞれほぼ相似性を示すので，ある一種の水銀ラン プの等価コンダクタンスのモデル定数より他の定格のモデル定数
が簡単に求められることを示す。このモデル定数を用いシミュレ 一ションにより他の定格の各素子の電圧、電流が簡単に高調波分 析可能であることを示す.ささらに, 入力端子電圧が変化してもラ ンプの電圧, 電流波形の相似性より, 各素子の電圧, 電流が簡単 に高調波分析できることを示す。

遅相形点灯回路と進相形点灯回路を並列に接続した高压水銀う ンプフリッカレス点灯回路の進相形点灯回路の素子のチョークコ イルの L とコンデンサの Cの組合せの值は無数に存在する。しか し, ランプの電圧, 電流について JIS 規格を満たす範囲でチョー クコイルの L とコンデンサの C の值の組合せを定めねばならな w.

$200 \mathrm{~W}$ 点灯回路で等価コンダクタンスのモデル定数を用いたシ ミュレーションにより, チョークコイルの L とコンデンサの Cの

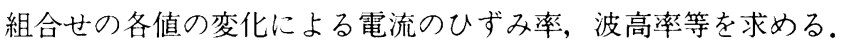
さらに, フリッカレス点灯回路の電源電流のUずみ率、力率等を 求め、L, Cの各組み合わせのいずれにおいても電源電流のUずみ 率がランプ電流のひずみ率より大きくなり, 電源電流の力率が 100 \%にならないことを示す。

\section{2. ランプの電圧, 電流の相似性による高調波分析理論}

2.1 等価コンダクタンスを用いたシュミレーションによる点 灯回路の高調波分析法

放電ランプ内での電子密度の単位時間当たりの変化割合は, 電 子密度の単位時間当たりの発生割合と消失割合の差で表せると仮 
定し, 放電ランプの電気的特性を等価コンダクタンス $\mathrm{G} て ゙$ 表すと, 次のような式が成り立つ3).

$$
\mathrm{G}=\frac{\mathrm{i}_{\mathrm{L}}}{v_{\mathrm{L}}}
$$

$\frac{\mathrm{dG}}{\mathrm{dt}}=\mathrm{A} \cdot \mathrm{i}_{\mathrm{L}}^{2}-\mathrm{C}_{\mathrm{C}} \cdot \mathrm{G}^{2}$

ただし， $\mathrm{G}$ は時間 $\mathrm{t}$ における等価コンダクタンスの瞬間值， $v_{\mathrm{L}}$, $\mathrm{i}_{\mathrm{L}}$ はランプの電圧, 電流の瞬間值とし， $\mathrm{A} ， \mathrm{C}_{\mathrm{c}}$ は定数である.

図 1 の進相形点灯回路において, 安定器 (チョークコイル)の 抵抗，自己インダクタンス及びコンデンサの容量をそれぞれ R, L及びCとする。 $\mathrm{e}=\mathrm{E} \sqrt{2} \sin (\omega \mathrm{t}-\boldsymbol{\varphi})$ の電压を印加したとす れば,

$\frac{\mathrm{di}_{\mathrm{L}}}{\mathrm{dt}}=\left\{\mathrm{E} \sqrt{2} \sin (\omega \mathrm{t}-\varphi)-(1 / \mathrm{G}+\mathrm{R}) \cdot \mathrm{i}_{\mathrm{L}}-\boldsymbol{v}_{\mathrm{C}}\right\} / \mathrm{L} \cdots \cdots(3$

$\frac{\mathrm{d} v_{\mathrm{L}}}{\mathrm{dt}}=\frac{\mathrm{i}_{\mathrm{L}}}{\mathrm{C}}$

ただし， $\varphi$ は電源電圧 $\mathrm{e}$ とランプ電流 $\mathrm{i}_{\mathrm{L}}$ との位相差で， $v_{\mathrm{C}}$ はコ ンデンサ電圧の瞬時值である.

(2) (4)式の三元連立微分方程式の E, A , C, L , R, C, $\omega$, $\varphi$ にそれぞれ值を与える。 さらに, 演算開始時間 $\mathrm{t}=\mathrm{O}$ の值とし て, 等価コンダクタンス $\mathrm{G}_{0}$, コンデンサ電圧 $\nu_{\mathrm{CO}}$, ランプ電流 $\mathrm{i}_{\mathrm{LO}}$ を定めると，ルンゲ・タッタ・ギル法などによる計算機演算によ って, ステップ時間 $\Delta \mathrm{t}$ ごとの $\mathrm{G}, \mathrm{i}_{\mathrm{L}}, v_{\mathrm{C}}$ 在求めることができる.

チョークコイル及びチョークコイル・コンデンサの端子電压の 瞬時值をそれぞれ $v_{\mathrm{en}}, v_{\mathrm{enc}}$ とすれば次の式が成り立つ.

$\left.\begin{array}{c}v_{\mathrm{ch}}=\mathrm{L} \frac{\mathrm{di}_{\mathrm{L}}}{\mathrm{dt}}+\mathrm{Ri}_{\mathrm{L}} \\ v_{\mathrm{ch} \cdot \mathrm{c}}=v_{\mathrm{cn}}+v_{\mathrm{c}}\end{array}\right\}$

(1)式により，ランプ電圧の瞬時值，(5)式より，千ョークコイル 及びチョークコイル・コンデンサのそれぞれの端子電圧の瞬時值 $v_{\mathrm{ch}}, v_{\mathrm{ch} . \mathrm{c}}$ は求まる. 後述の(13)式により各素子の電圧, 電流の各調波 の大きさ及び位相が求まる。

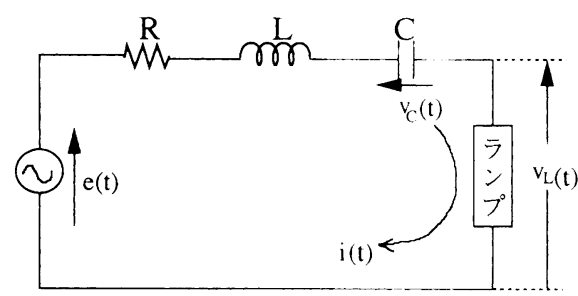

図 1 進相形点灯回路

2.2 ランプ電圧, 電流の相似性にもとづくモデル定数の算出法

図 2 に示すように時間 $\mathrm{t}$ に対して $v_{\mathrm{L}}, \mathrm{i}_{\mathrm{L}}$ が点線のように変化 するものとする.

モデル定数 $\mathrm{A}, \mathrm{C}_{\mathrm{c}}, \mathrm{i}_{\mathrm{L} 1}\left(\mathrm{~d} v_{\mathrm{L}} / \mathrm{dt}\right)_{2}$ の間には, 次式が成り立つ ${ }^{3)}$.

$\left(\mathrm{A} \cdot \mathrm{i}_{\mathrm{L} 1}{ }^{2}-\mathrm{C}_{\mathrm{c}} \cdot \mathrm{G}_{1}^{2}\right) v_{\mathrm{L} 1}=\left(\mathrm{di}_{\mathrm{L}} / \mathrm{dt}\right)_{1}$

$\left.\left(\mathrm{A} \cdot \mathrm{i}_{\mathrm{L}_{2}}^{2}-\mathrm{C}_{\mathrm{c}} \cdot \mathrm{G}_{2}^{2}\right) v_{\mathrm{L} 2}+\mathrm{G}_{2}\left(\mathrm{~d} \boldsymbol{r}_{\mathrm{L}} / \mathrm{dt}\right)_{2}=0\right\}$

ただし, ランプ電圧, 電流が最大となる時刻をそれぞれ $\mathrm{t}_{1}, \mathrm{t}_{2}$ とし， $\mathrm{i}_{\mathrm{L} 1} \sim\left(\mathrm{d} \iota_{\mathrm{L}} / \mathrm{dt}\right)_{2}$ はそれぞれのときの各值を添字 $1 ， 2$ で 示す.

また，次式が成り立つ。
$\left.\begin{array}{l}\mathrm{G}_{1}=\mathrm{i}_{\mathrm{L} 1} / \boldsymbol{v}_{\mathrm{L} 1} \\ \mathrm{G}_{2}=\mathrm{i}_{\mathrm{L} 2} / \boldsymbol{v}_{\mathrm{L} 2}\end{array}\right\}$

(6)，(7)式より，モデル定数 $\mathrm{A} ， \mathrm{C}_{\mathrm{c}}$ は次式で与えられる3).

$\mathrm{A}=\frac{-\frac{1}{v_{\mathrm{L} 2}^{2}}\left\{\frac{i_{\mathrm{L} 2}^{2}}{v_{\mathrm{L} 1}} \cdot\left(\frac{d i_{\mathrm{L}}}{d t}\right)_{1}+i_{\mathrm{L} 2} \cdot\left(\frac{d v_{\mathrm{L}}}{d t}\right)_{2} \cdot\left(\frac{i_{\mathrm{L} 1}}{v_{\mathrm{L} 1}}\right)^{2}\right\}}{-i_{\mathrm{L}, 1}^{2} \cdot i_{\mathrm{L} 2}^{2}\left\{\left(\frac{1}{v_{\mathrm{L} 2}}\right)^{2}-\left(\frac{1}{v_{\mathrm{L} 1}}\right)^{2}\right\}}$
$\mathrm{C}_{\mathrm{c}}=\frac{-\frac{1}{v_{\mathrm{L} 2}^{2}}\left\{i_{\mathrm{L} 2} \cdot i_{\mathrm{L} 1}^{2} \cdot\left(\frac{d v_{\mathrm{L}}}{d t}\right)_{2}+v_{\mathrm{L} 2}^{2} \cdot i_{\mathrm{L} 2}^{2} \cdot \frac{1}{v_{\mathrm{L} 1}} \cdot\left(\frac{d i_{\mathrm{L}}}{d i}\right)_{1}\right\}}{-i_{\mathrm{L} 1}^{2} \cdot i_{\mathrm{L} 2}^{2}\left\{\left(\frac{1}{v_{\mathrm{L} 2}}\right)^{2}-\left(\frac{1}{v_{\mathrm{L} 1}}\right)^{2}\right\}}$

ランプに関する数値の $\mathrm{i}_{\mathrm{L}, 1} \sim\left(\frac{\mathrm{d} \boldsymbol{\nu}_{\mathrm{L}}}{\mathrm{dt}}\right)_{2}$ を(8)式に代入すると，モ デル定数 $\mathrm{A}, \mathrm{C}_{\mathrm{c}}$ は求まる。

各種定格の進相形点灯回路のランプの電压, 電流のそれぞれの 波形について, 横軸方向, 縦軸方向の大きさをそれぞれ一定の比 で変化することにより，ほぼ重ねることができるとき，ランプの 電圧，電流波形はそれぞれの相似であると定義する。

ランプ電圧，電流のそれぞれの波形が相似で，電圧，電流の最 大值がそれぞれ $\alpha_{\mathrm{v}}, \alpha_{1}$ 倍のときは，四にの実線で示すようにいず れの瞬時においてもランプ電压, 電流 $v_{\mathrm{L}}{ }^{\prime}, \mathrm{i}_{\mathrm{L}}{ }^{\prime}$ はそれぞれ $\alpha_{\mathrm{v}}, v_{\mathrm{L}}$, $\alpha_{\mathrm{i}} \mathrm{i}_{\mathrm{L}}$ となる.

この場合のの等価コンダクタンスのモデル定数 $\mathrm{A}, \mathrm{C}_{\mathrm{c}}{ }^{\prime}$ 'は(8)式 と同様に

$$
\begin{aligned}
& \mathrm{A}^{\prime}=\frac{-\frac{1}{v_{\mathrm{L} 2}^{\prime 2}}\left\{\frac{i_{\mathrm{L} 2}^{\prime 2}}{v_{\mathrm{L} 1}^{\prime}} \cdot\left(\frac{d i_{\mathrm{L}}^{\prime}}{d t}\right)_{1}+i_{\mathrm{L} 2}^{\prime} \cdot\left(\frac{d v_{\mathrm{L}}^{\prime}}{d t}\right)_{2} \cdot\left(\frac{i_{\mathrm{L} 1}^{\prime}}{v_{\mathrm{L} 1}^{\prime}}\right)^{2}\right\}}{-i_{\mathrm{L} 1}^{\prime 2} \cdot i_{\mathrm{L} 2}^{\prime 2}\left\{\left(\frac{1}{v_{\mathrm{L} 2}^{\prime}}\right)^{2}-\left(\frac{1}{v_{\mathrm{L} 1}^{\prime}}\right)^{2}\right\}} \\
& \mathrm{C}_{\mathrm{c}}^{\prime}=\frac{-\frac{1}{v_{\mathrm{L} .2}^{\prime 2}}\left\{i_{\mathrm{L} 2}^{\prime} \cdot i_{\mathrm{L}, 1}^{\prime 2} \cdot\left(\frac{d v_{\mathrm{L}}^{\prime}}{d t}\right)_{2}+v_{\mathrm{L}, 2}^{\prime 2} \cdot i_{\mathrm{L} 2}^{\prime 2} \cdot \frac{1}{v_{\mathrm{L}}^{\prime}} \cdot\left(\frac{d i_{\mathrm{L}}^{\prime}}{d i}\right)_{1}\right\}}{-i_{\mathrm{L}, 1}^{\prime 2} \cdot i_{\mathrm{L}, 2}^{\prime 2}\left\{\left(\frac{1}{v_{\mathrm{L} 2}^{\prime}}\right)^{2}-\left(\frac{1}{v_{\mathrm{L}, 1}}\right)^{2}\right\}}
\end{aligned}
$$

ただし，ランプ電圧，電流が最大となる時間をそれぞれ $\mathrm{t}_{1}, \mathrm{t}_{2}$ とし，それぞれの各值を添字 $1 ， 2$ で表す。

図2より，次式が成り立つ。

$$
\left.\begin{array}{l}
i_{\mathrm{L} 1}^{\prime}=\alpha_{i} i_{\mathrm{L} 1} \\
i_{\mathrm{L} 2}^{\prime}=\alpha_{i} i_{\mathrm{L} 2} \\
\left(\alpha i_{\mathrm{L}}^{\prime} / d t\right)_{1}=\alpha_{i}\left(d t_{\mathrm{L}} / d t\right)_{1}
\end{array}\right\}
$$

モデル定数 $\mathrm{A}^{\prime} ， \mathrm{C}_{\mathrm{c}}^{\prime}$ は(10)，(11)式を(9)式に代入し，さらに，(8)式よ ),

$$
\left.\begin{array}{l}
\mathrm{A}^{\prime}=\frac{-\frac{1}{v_{\mathrm{L} 2}^{2}}\left\{\frac{i_{\mathrm{L} 2}^{2}}{v_{\mathrm{L}, 1}} \cdot\left(\frac{d i_{\mathrm{L}}}{d t}\right)_{1}+i_{\mathrm{L} 2} \cdot\left(\frac{d v_{\mathrm{L}}}{d t}\right)_{2} \cdot\left(\frac{i_{\mathrm{L} 1}}{v_{\mathrm{L} 1}}\right)^{2}\right\}}{-\alpha_{i} \cdot \alpha_{v} \cdot i_{\mathrm{L},}^{2} \cdot i_{\mathrm{L} 2}^{2}\left\{\left(\frac{1}{v_{\mathrm{L} 2}}\right)-\left(\frac{1}{v_{\mathrm{L} 1}}\right)^{2}\right\}}=\frac{\mathrm{A}}{\alpha i \cdot \alpha_{v}} \\
\mathrm{C}_{\mathrm{c}}^{\prime}=\frac{-\frac{\alpha_{v}}{v_{\mathrm{L} 2}^{2}}\left\{i_{\mathrm{L} 2} \cdot i_{\mathrm{L} 1}^{2} \cdot\left(\frac{d v_{\mathrm{L}}}{d t}\right)_{2}+v_{\mathrm{L} 2}^{2} \cdot i_{\mathrm{L}, 2}^{2} \cdot \frac{1}{v_{\mathrm{L} 1}} \cdot\left(\frac{d i_{\mathrm{L}}}{d t}\right)_{1}\right\}}{-\alpha_{i} \cdot i_{\mathrm{L} 1}^{2} \cdot i_{\mathrm{L} 2}^{2}\left\{\left(\frac{1}{v_{\mathrm{L} 2}}\right)-\left(\frac{1}{v_{\mathrm{L} 1}}\right)^{2}\right\}}=\frac{\alpha_{v}}{\alpha_{i}} \mathrm{C}_{\mathrm{c}}
\end{array}\right\}
$$

となる。

A， $\mathrm{C}_{\mathrm{c}}$ 'はそれぞれ $\mathrm{A}, \mathrm{C}_{\mathrm{c}}$ の $1 /\left(\alpha_{1} \alpha_{\mathrm{v}}\right), \alpha_{\mathrm{v}} / \alpha_{\mathrm{i}}$ 倍となり，あ る一種の定格点灯回路のモデル定数 $\mathrm{A}, \mathrm{C}_{\mathrm{c}}$ と $\alpha_{\mathrm{v}}, \mathrm{a}_{1}$ から, 各種 定格点灯回路のモデル定数は簡単に求まることになる。したがっ て, 2.1で記述した方法で各種定格点灯回路の各素子の電圧, 電流 
を高調波分析できることになる。

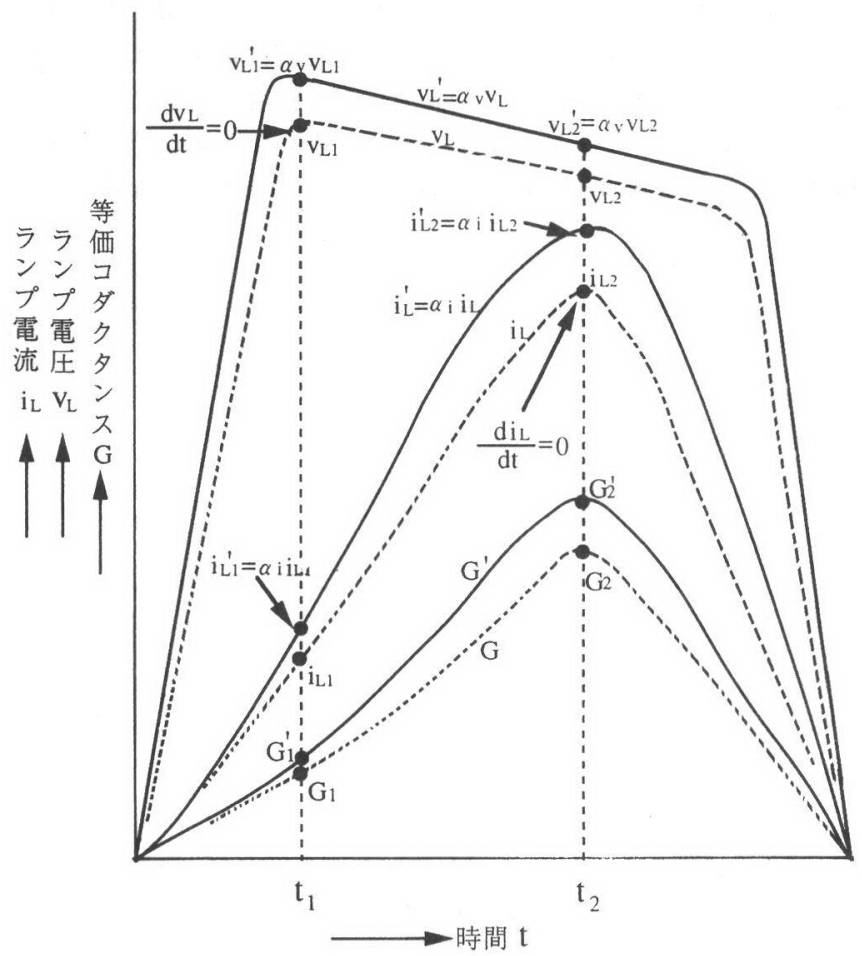

図2 ランプの電圧, 電流, コンダクタンスの波形

3. 高圧水銀ランプ点灯回路のシミュレーションに 上る高調波分析

\section{1 各種定格進相形点灯回路の高調波分析}

以下，安定点灯時の高調波分析について述べる.

各種定格進相形点灯回路のランプの電圧，電流波形をそれぞれ

図 3 に示す。ただし，入力端子電圧は $200 \mathrm{~V}, 60 \mathrm{~Hz}$ とする。

ランプ定格電力 $200 \mathrm{~W}$ 点灯回路のランプ電圧, 電流のそれぞれ の波形に対して，ランプ定格電力 $250 ， 300 ， 400 ， 700 ， 1000 \mathrm{~W}$ の それぞれの点灯回路のランプの電圧, 電流波形の横軸, 縦軸方向 の大きさをそれぞれ一定の比で小さくすることにより，ほぼ重ね ることができる.したがって, ランプ定格電力 $200 \mathrm{~W}$ 点灯回路のラ ンプ電圧，電流波形とほぼ相似であると考えてよい。また，これ らの各種定格点灯回路のそれぞれのランプ電圧，電流波形は互い にほぼ相似であることを意味している。

図 3 の $200 \mathrm{~W}$ 点灯回路のランプ電圧, 電流の波形より求めた表 $1 の v_{\mathrm{L} 1} \sim\left(\mathrm{d} \nu_{\mathrm{L}} / \mathrm{dt}\right)_{2}$ のランプに関する数值を(8)式に代入してモデ 儿定数 $\mathrm{A}, \mathrm{C}_{\mathrm{c}}$ を求めると,

$$
\left.\begin{array}{c}
\mathrm{A}=8.26 \\
\mathrm{C}_{\mathrm{c}}=12.3 \times 10^{4}
\end{array}\right\}
$$

となる.

$200 \mathrm{~W}$ 進相形点灯回路の表 2 の $\mathrm{E} \sim \varphi$ の回路に関する数值及び (13)式を(2) 〜 (4)式に代入し, さらに演算開始時間 $\mathrm{t}=0$ の值として, 表 3 の数值を与え, $1 \mathrm{~Hz}$ を 180 等分する.

(2) (4)式の三元連立微分方程式及び(5)式からシミュレーション による各素子の電圧, 電流の瞬時値を電源電圧べースに直して求 め, さらに,

$$
\begin{gathered}
a_{n}=\frac{1}{m} \sum_{s=0}^{2 m-1} y(s \cdot \Delta t) \cos (s \cdot n \cdot \Delta t) \\
(n=0,1,2 \cdots \cdots \cdots) \\
b_{n}=\frac{1}{m} \sum_{s=0}^{2 m-1} y(s \cdot \Delta t) \sin (s \cdot n \cdot \Delta t) \\
(n=0,1,2 \cdots \cdots \cdots)
\end{gathered}
$$

により, 各調波フーリエ係数を算出し, 各調波の大きさ及び位相 角を求める。

$200 \mathrm{~W}$ 点灯回路のランプの各調波電圧, 電流の成分及びランプ 電力についてシミュレーションにより求めた值及び実測により求 めたそれらを表 4 に示す. ただし, $\mathrm{V}_{\mathrm{L} 1}$ と $\mathrm{I}_{1}, \mathrm{~V}_{\mathrm{L} 3}$ と $\mathrm{I}_{3}, \mathrm{~V}_{\mathrm{L} 5}$ と $\mathrm{I}_{5}$ はそれぞれランプの基本波, 第 3 , 第 5 調波電圧と電流の大きさを、 $\phi_{\mathrm{L} 1}$ と $\theta_{1}, \phi_{\mathrm{L} 3}$ と $\theta_{3}, \phi_{\mathrm{L} 5}$ と $\theta_{5}$ はそれらの位相角を示すが, 以下表 8，12，14及び17も同じ.

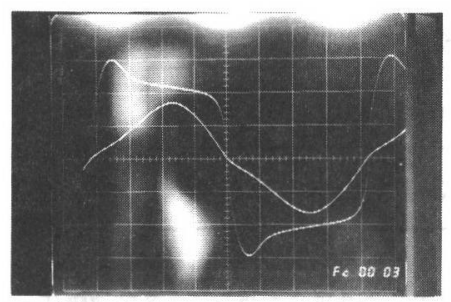

(a) $100 \mathrm{~W} 50 \mathrm{v} / \mathrm{div}$
$1 \mathrm{~A} / \mathrm{div}$

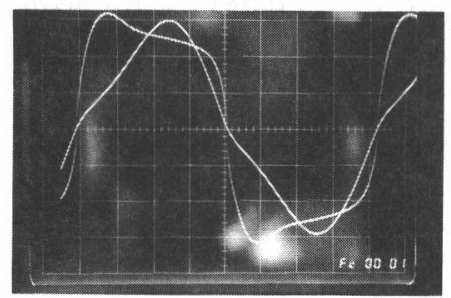

(b) $200 \mathrm{w} \quad 50 \mathrm{~V} / \mathrm{div}$

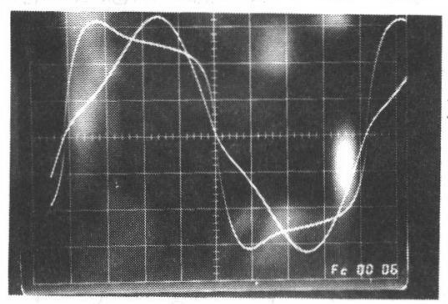

(c) $250 \mathrm{~W} 50 \mathrm{~W} / \mathrm{div}$ IA/div

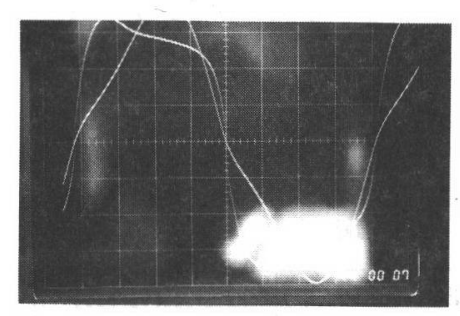

(d) $300 \mathrm{w} \quad 50 \mathrm{~V} / \mathrm{div}$
$1 \mathrm{~A} / \mathrm{div}$

図 3 各種定格進相形点灯回路のランプ電圧, 電流波形

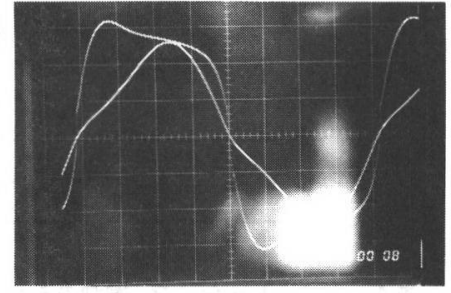

(e) $400 \mathrm{~W} \quad 50 \mathrm{~V} / \mathrm{div}$
$2 \mathrm{~A} / \mathrm{div}$

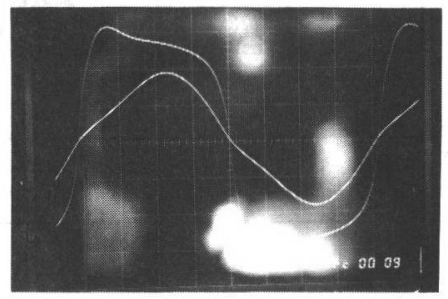

(f) 700W $50 \mathrm{~V} / \mathrm{div}$

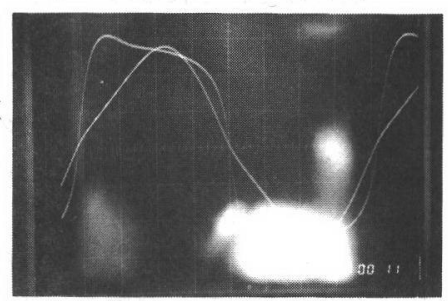

(g) 1000W 50V/div 
表 1 モデル定数算出のためのランプに関する数值 $(200 \mathrm{~W}$ 准相形占灯回路)

\begin{tabular}{|c|c|c|c|c|c|}
\hline $\begin{array}{l}\mathrm{V}_{\mathrm{L} 1} \\
{[\mathrm{~V}]}\end{array}$ & $\begin{array}{r}\mathrm{i}_{\mathrm{L} 1} \\
{[\mathrm{~A}]}\end{array}$ & $\begin{array}{c}{\left[\mathrm{d} \mathrm{i}_{\mathrm{L}} / \mathrm{dt}\right]_{1}} \\
{[\mathrm{~A} / \mathrm{S}]}\end{array}$ & $\begin{array}{r}\mathrm{V}_{\mathrm{L} 2} \\
{[\mathrm{~V}]}\end{array}$ & $\begin{array}{c}\mathrm{i}_{\mathrm{L} 2} \\
{[\mathrm{~A}]}\end{array}$ & $\begin{array}{c}{\left[\mathrm{dV}_{\mathrm{L}} / \mathrm{dt}\right]_{2}} \\
{[\mathrm{~V} / \mathrm{S}]}\end{array}$ \\
\hline 157 & 1.07 & 588.0 & 123.0 & 2.97 & -6000 \\
\hline
\end{tabular}

表 2 回路に関する数值 $200 \mathrm{~W}$ 進相形点灯回路

\begin{tabular}{|l|c|c|c|c|c|}
\hline $\begin{array}{l}\mathrm{E} \\
{[\mathrm{v}\rfloor}\end{array}$ & $\begin{array}{c}\mathrm{L} \\
{[\mathrm{H}]}\end{array}$ & $\begin{array}{c}\mathrm{C} \\
{[\mu \mathrm{F}]}\end{array}$ & $\begin{array}{c}\mathrm{R} \\
{[\Omega]}\end{array}$ & $\begin{array}{c}\omega \\
\lceil\mathrm{rad} / \mathrm{s}\rfloor\end{array}$ & $\begin{array}{c}\psi \\
{\left[{ }^{\circ}\right\rfloor}\end{array}$ \\
\hline 200 & 0.181 & 15.5 & 3.19 & $2 \pi \times 60$ & 56 \\
\hline
\end{tabular}

表 3 シミュレーションのための初期值 (200W 進相形点灯回路)

\begin{tabular}{|c|c|c|}
\hline 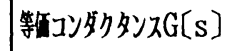 & 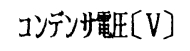 & 今電流[A] \\
\hline 0.01 & -315 & 0 \\
\hline
\end{tabular}

表 4 シミュレーション, 実測のそれぞれにより求めたランプの各調波電圧, 電流及びランプ電力 (200W 進相形点灯回路)

\begin{tabular}{|c|c|c|c|c|c|c|c|}
\hline & 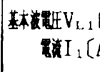 & $\begin{array}{l}\text { V] } \phi_{L, 1}\left({ }^{0}\right] \\
\text { i] } \theta_{1}\left[0^{\circ}\right]\end{array}$ & 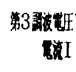 & $\begin{array}{c}\text { V] } \phi_{L, 3}\left[{ }^{\circ}\right] \\
\theta_{3}\left[{ }^{\circ}\right]\end{array}$ & 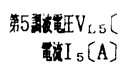 & $\begin{array}{l}\phi_{L 5}\left({ }^{\circ}\right) \\
\theta_{5}\left({ }^{\circ}\right)\end{array}$ & $\begin{array}{l}5 y 9 \\
\text { to }\end{array}$ \\
\hline ジュレーション & $\begin{array}{l}116.0 \\
1.89\end{array}$ & $\begin{array}{r}68.2 \\
-52.1\end{array}$ & $\begin{array}{l}34.71 \\
0.235\end{array}$ & $\begin{array}{l}178.7 \\
-90.1\end{array}$ & $\begin{array}{l}13.67 \\
0.0445\end{array}$ & $\begin{array}{r}-76.1 \\
14.5\end{array}$ & 210 \\
\hline 実測 & $\begin{array}{l}116.4 \\
1.89\end{array}$ & $\begin{array}{l}69.6 \\
54.4\end{array}$ & $\begin{array}{l}33.76 \\
0.239\end{array}$ & $\begin{array}{r}182.3 \\
-81.0\end{array}$ & $\begin{array}{l}13.68 \\
0.0438\end{array}$ & $\begin{array}{r}-61.1 \\
34.8\end{array}$ & 211 \\
\hline
\end{tabular}

シミュレーションにより求佑各調波電圧，電流の大きさ， う ンプ電力はそれぞれはば来測值に等しい，即ち，各調波電压，電 流の大きさ及びランプ電力に関してはシミュレーションによる算 出結果の精度が高いことを示している。また, シミュレーション により求めた各調波電圧，電流の位相角はそれぞれ垁測値との䛊 差は小さいが次数が大きくなるにつれて大きくなっている.

200W 点灯回路について，シミュレーションより求めたチョー クコイル，コンデンサのそれぞれの各調波の電圧の成分及び奏測 により求めたそれらを表 5 に示守。ただし， $V_{\mathrm{ch} 1}$ と $\phi_{\mathrm{ch} 1}, \mathrm{~V}_{\mathrm{ch} 3}$ と $\phi_{\mathrm{ch} 3}, V_{\mathrm{ch} 5}$ と $\phi_{\mathrm{ch} 5}$ 牥それぞれチョㄱコイルの基本波，第3，第5調 波電圧の大きさとそれらの位相角を亦子。また, $V_{\mathrm{C} 1}$ と $\phi_{\mathrm{C} 1} 、 \mathrm{~V}_{\mathrm{C} 3}$ と $\phi_{\mathrm{C} 3}, \mathrm{~V}_{\mathrm{C} 5}$ と $\phi_{\mathrm{C} 5}$ はそ㣔ぞれコンデンサの基本波，第3，第5調波

表 5 シミュレーション, 実測のそれぞれにより求めたチョークコイルとコン デンサの各調波電圧 $200 \mathrm{~W}$ 谁相形点灯回路)

\begin{tabular}{|c|c|c|c|c|c|}
\hline & 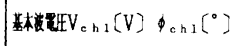 & 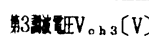 & $\operatorname{loh}_{0}\left[0^{\circ}\right]$ & 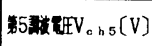 & $\phi_{0 h 5}\left[{ }^{\circ}\right]$ \\
\hline ジュレーショツ & $128.9 \quad 138.6$ & 48.1 & -3.9 & 15.19 & 99.0 \\
\hline \multirow[t]{2}{*}{ 実測 } & $128.9 \quad 140.7$ & 47.2 & 5.6 & 16.08 & 122.1 \\
\hline & 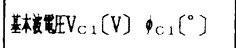 & 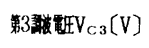 & $\phi_{\mathrm{C} 3}\left[{ }^{\circ}\right]$ & 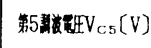 & $\varphi_{C 5}\left[{ }^{\circ}\right]$ \\
\hline シシュレーション & $322.9-37.9$ & 13.41 & 179.9 & 1.52 & -75.5 \\
\hline 実測 & $319.2-35.6$ & 12.24 & 187 & 2.27 & -52.3 \\
\hline
\end{tabular}

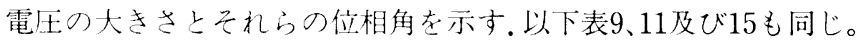
この場合もシミュレーションにより求めた各調波電圧の大きさ はそれぞれはぼ央測值に等しい，即ち，各調波電圧の大きさに関 してはシミュレーションによる算出結果の精度が高いことを示し ている。また，シミュレーションにより求めた各調波電在の位相 角はそれぞれ実測值との鿁差が小さいが次数が大きくなるにつれ て僅かだけ大きくなっている。

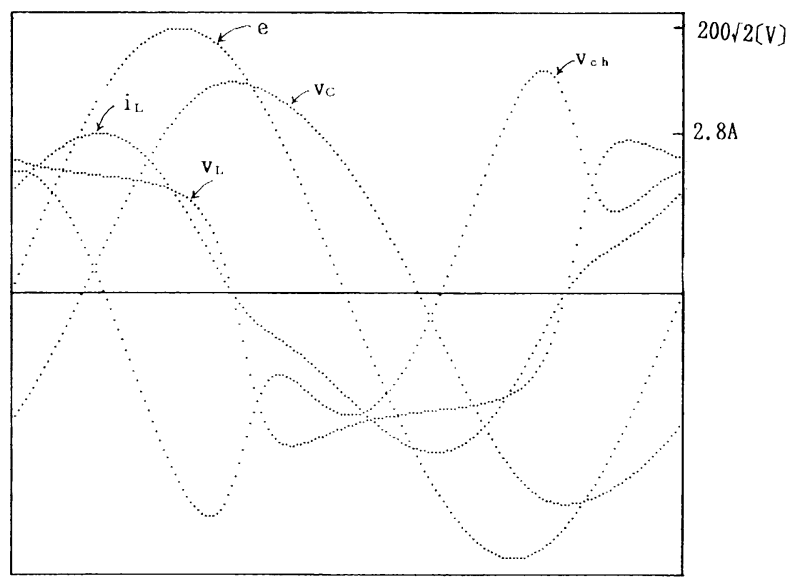

図 4 シミュレーションによる各素子の電圧, 電流波形 $(\mathrm{L}=0.181 \mathrm{H}, \mathrm{C}=15.5$ $\mu \mathrm{F})\left(た た し ， V_{\mathrm{C}}\right.$ のスケールは2倍)

シミュレーションによる各素子の電圧、電流波形を図4に示す. 高压水銀ランプ点灯回路の各種定格のランプ電力, 電流, 電在 と本論文で用いた各種定格進相形点灯回路に対古るチョークコイ

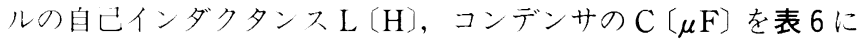
示多。また，ランプ電力、電流、電圧を同じく表6に示すがそれぞ 礼はば定格值に近い。

表 6 高圧水銀ランプ点灯回路の定格ランプ電力, 電流, 電圧と本論文で用い たチョークコイルの $\mathrm{L}[\mathrm{H}]$, コンデンサの $\mathrm{C}[\mu \mathrm{F}]$ とランプ電力, 電流, 電圧

\begin{tabular}{|c|c|c|c|c|c|c|}
\hline $\begin{array}{l}\text { 定格ランプ } \\
\text { 電力 }[W]\end{array}$ & 200 & 250 & 300 & 400 & 700 & 1000 \\
\hline $\begin{array}{l}\text { 定格ランプ } \\
\text { 電流 }[A]\end{array}$ & 1. 9 & 2. 1 & 2. 5 & 3.3 & 5. 9 & 8. 3 \\
\hline $\begin{array}{l}\text { 定格ランプ } \\
\text { 電压 }(\mathrm{V})\end{array}$ & 120 & 120 & 130 & 130 & 130 & 130 \\
\hline$f_{3}-ク \sqsupset\{k[\mathrm{H}]$ & 0.181 & 0.152 & 0.1335 & 0.0919 & 0.0606 & 0.0437 \\
\hline コンデンサ $[\mu \mathrm{F}]$ & 15.5 & 17.5 & 21.2 & 28.5 & 49.5 & 70.5 \\
\hline 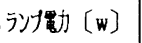 & 213 & 236 & 313 & 415 & 712 & 950 \\
\hline 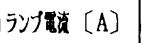 & 1.9 & 2.1 & 2.5 & 3.3 & 6.0 & 8.3 \\
\hline $5 y 9$ 粕 $(\mathrm{V})$ & 125 & 125 & 135 & 127 & 127 & 124 \\
\hline
\end{tabular}

各種定格点灯回路について、200W 点灯回路に対する $\mathrm{a}_{\mathrm{v}} 、 \mathrm{a}_{\mathrm{i}}$ を 求めると表 7 のうになる。 $\alpha_{\mathrm{v}} ， \alpha_{\mathrm{i}}$ のそれぞれの值を(12)式に代入 して求めたモデル定数 $\mathrm{A}, \mathrm{C}_{\mathrm{C}}$ を同じく表7に示す.

各種定格点灯回路のそれぞれのモデル定数を用いて，200W 点 灯回路のときと同様にシミュレーションにより求めた各種定格点 灯回路のランプの各調波電圧，電流の成分及び実測により求めた 
それらを表 8 に示す、表 8 によと,ランプの各調波電压に関して, 何れの定格の場合も，大きさ位相角の両方共にシミュレーション 及び実測により求めたそれぞれの值はほぼ等しい。また，各種定 格共に，大きさ位相角の両方とも互いにほぼ等しく，ほぼ同じ電 压波形であることを意味している。

ランプの各調波電流に関しては定格が人きくなるに伴って大き くなっており，位相角は各種定格共ほぼ等しく互いにほぼほぼ相 似性老保っていることを意味している.

250, 300W 点灯回路について, シミュレーション, 実測のそれ

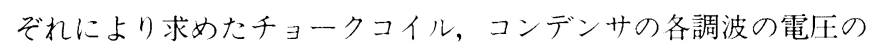
成分を表 9 に示す。

シミュレーションにより求めた各調波電压の大きさはそれぞれ ほぼ㿤测值に等しい，即ち，各調波電圧の大きさに関してはシミ ュレーションによる算出結果の精度が高いことを示している。 ミュレーションにより求めた各調波電压の位相角はそれぞれ実測 值と䛊差が小さいが次数が大きくなるにつれて僅かだけ大きくな っている.

$1000 \mathrm{~W}$ 点灯回路について、ランプ電压、電流の相似性により 200, $400 \mathrm{~W}$ 基集にしてそれぞれ求めたモデル定数及び春測により 求めたモデル定数を表10に示す。これらのモデル定数はほぼ等し い.

1000W 点灯回路について, シミュレーション (400W 基準)、実 測のそれぞれにより求めたチョークコイル，コンデンサの各調波 の電圧の成分を表11に示す。

表 7 各種定格点灯回路ランプの電流, 電圧の乗数とモデル定数 $(200 \mathrm{~W})$ 基準

\begin{tabular}{|c|c|c|c|c|}
\hline \multirow{2}{*}{$\begin{array}{l}\text { 定格ランプ } \\
\text { 奄力[W] }\end{array}$} & \multicolumn{2}{|c|}{ モデル定数 } & \multirow{2}{*}{$\alpha_{i}$} & \multirow{2}{*}{$\alpha_{v}$} \\
\hline & A & $\mathrm{C}_{c}$ & & \\
\hline 200 & 8.26 & $12.30 \times 10^{4}$ & 1 & 1 \\
\hline 250 & 8. 48 & $11.13 \times 10^{4}$ & 1.105 & 1.000 \\
\hline 300 & 5. 81 & $10.09 \times 10^{4}$ & 1.316 & 1.080 \\
\hline 400 & 4. 68 & $7.19 \times 10^{4}$ & 1.737 & 1.016 \\
\hline 700 & 2. 57 & $3.96 \times 10^{4}$ & 3.158 & 1.016 \\
\hline 1000 & 1. 91 & $2.79 \times 10^{4}$ & 4.368 & 0.992 \\
\hline
\end{tabular}

250, 300W 点灯回路のときと同様にシミュレーションにより求 めた各調波電圧の大きさはそれぞれは涪実測值に等しい。即ち， 各調波電圧の大きさに関してはシミュレーションによる算出結果 の精度が高いことを示している。シミュレーションにより求めた 各調波電圧の位相角はそれぞれ実測值と誤差が小さいが次数が大 きくなるにつれて僅かだけ大きくなっている.

$100 \mathrm{~W}$ 点灯回路 $(\mathrm{L}=0.358 \mathrm{H}, \mathrm{R}=9.0 \Omega, \mathrm{C}=8.57 \mu \mathrm{F})$ のモデル定 数 $\mathrm{A} 、 \mathrm{C}_{\mathrm{c}}$ 在図 $3(\mathrm{a})$ のランプ電圧, 電流の波形より求めると,

$\left.\begin{array}{l}\mathrm{A}=21.19 \\ \mathrm{C}_{\mathrm{C}}=25.4 \times 10^{4}\end{array}\right\}$

$200 \mathrm{~W}$ 点灯回路 $(\mathrm{L}=0.181 \mathrm{H}, \mathrm{R}=3.19 \Omega, \mathrm{C}=15.5 \mu \mathrm{F}) \sigma 100 \mathrm{~W}$ 点 灯回路に対卞るランプ電压, 電流のそれぞれの乗数 $\alpha_{\mathrm{v}}, \mathrm{a}_{i}$ は 100

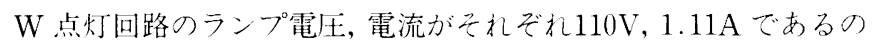
で,

$\alpha_{\mathrm{v}}=125 / 110=1.136, \quad \alpha_{\mathrm{i}}=1.9 / 1.11=1.712$ となる．
これらを(12)式に代入して200W 点灯回路のモデル定数 $\mathrm{A}^{\prime}$ 、 $\mathrm{C}_{\mathrm{C}}{ }^{\prime}$ 救好る々。

$$
\left.\begin{array}{l}
\mathrm{A}^{\prime}=10.89 \\
\mathrm{C}_{\mathrm{C}^{\prime}}=16.8 \times 10^{4}
\end{array}\right\}
$$

となる。

$200 \mathrm{~W}$ 点灯回路 $(\mathrm{L}=0.181 \mathrm{H}, \mathrm{R}=3.19 \Omega, \mathrm{C}=15.5 \mu \mathrm{F})$ について, (16)式のモデル定数を用いてシミュレーションにより求めたランプ

表 8 各種定格点灯回路のシミュレーション (200W 基準 $\}$ 及び実測のそれぞ

\begin{tabular}{|c|c|c|c|c|c|c|c|c|}
\hline 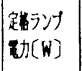 & 方法 & 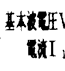 & [v] $\begin{array}{c}\left.\phi_{L}, 5^{\circ}\right] \\
\quad \theta_{1}\left[^{\circ}\right]\end{array}$ & 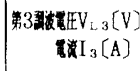 & $\begin{array}{l}\phi_{1,3}\left[0^{\circ}\right] \\
\theta_{3}\left[0^{\circ}\right]\end{array}$ & 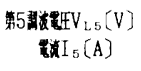 & $\begin{array}{l}\theta_{\operatorname{Lis}}\left(0^{\circ}\right] \\
\theta_{5}\left[{ }^{\circ}\right]\end{array}$ & 实 \\
\hline & $\begin{array}{l}\text { 添ע- } \\
\text { ション }\end{array}$ & $\begin{array}{r}116.3 \\
2.06\end{array}$ & $\begin{array}{l}68.4 \\
51.8\end{array}$ & $\begin{array}{l}33.9 \\
0.279\end{array}$ & $\begin{array}{l}178.3 \\
-90.2\end{array}$ & $\begin{array}{l}12.72 \\
0.049\end{array}$ & $\begin{array}{r}-75.2 \\
15.5\end{array}$ & 230 \\
\hline & 実測 & $\begin{array}{r}119.6 \\
2.09\end{array}$ & $\begin{array}{l}68.2 \\
52.3\end{array}$ & $\begin{array}{l}34.3 \\
0.287\end{array}$ & $\begin{array}{l}176.1 \\
-86.6\end{array}$ & $\begin{array}{l}12.84 \\
0.050\end{array}$ & $\begin{array}{r}-64.9 \\
29.9\end{array}$ & 238 \\
\hline & $\begin{array}{l}\text { 添V } \\
\text { ション }\end{array}$ & $\begin{array}{r}125.5 \\
2.54\end{array}$ & $\begin{array}{l}64.9 \\
48.4\end{array}$ & $\begin{array}{l}37.0 \\
0.338\end{array}$ & $\begin{array}{r}168.5 \\
-100.0\end{array}$ & $\begin{array}{l}14.18 \\
0.063\end{array}$ & $\begin{array}{r}-91.8 \\
-1.1\end{array}$ & 305 \\
\hline & 実測 & $\begin{array}{r}130.0 \\
2.57\end{array}$ & $\begin{array}{l}65.3 \\
47.2\end{array}$ & $\begin{array}{l}36.3 \\
0.337\end{array}$ & $\begin{array}{r}160.5 \\
-102.1\end{array}$ & $\begin{array}{l}13.48 \\
0.060\end{array}$ & $\begin{array}{r}-93.3 \\
1.2\end{array}$ & 313 \\
\hline & $\begin{array}{l}\text { 泫al } \\
\text { ション }\end{array}$ & $\begin{array}{r}119.1 \\
3.33\end{array}$ & $\begin{array}{l}68.1 \\
51.2\end{array}$ & $\begin{array}{l}34.8 \\
0.476\end{array}$ & $\begin{array}{l}178.2 \\
-90.4\end{array}$ & $\begin{array}{l}13.08 \\
0.085\end{array}$ & $\begin{array}{r}-74.3 \\
16.3\end{array}$ & 400 \\
\hline & 実湖 & $\begin{array}{r}121.3 \\
3.40\end{array}$ & $\begin{array}{l}67.2 \\
50.3\end{array}$ & $\begin{array}{l}33.5 \\
0.468\end{array}$ & $\begin{array}{l}173.8 \\
-95.1\end{array}$ & $\begin{array}{l}12.88 \\
0.084\end{array}$ & $\begin{array}{r}-70.7 \\
3.4\end{array}$ & 388 \\
\hline & $\begin{array}{l}\text { 洋y- } \\
\text { 浔y }\end{array}$ & $\begin{array}{r}117.7 \\
6.19\end{array}$ & $\begin{array}{l}66.0 \\
50.5\end{array}$ & $\begin{array}{l}35.6 \\
0.701\end{array}$ & $\begin{array}{r}171.4 \\
-96.5\end{array}$ & $\begin{array}{l}14.23 \\
0.137\end{array}$ & $\begin{array}{r}-88.6 \\
2.1\end{array}$ & 702 \\
\hline & 実測 & $\begin{array}{r}121.6 \\
6.13\end{array}$ & $\begin{array}{l}66.9 \\
51.2\end{array}$ & $\begin{array}{l}35.4 \\
0.690\end{array}$ & $\begin{array}{r}160.5 \\
-103.4\end{array}$ & $\begin{array}{l}14.11 \\
0.136\end{array}$ & $\begin{array}{r}-82.7 \\
6.4\end{array}$ & 713 \\
\hline & $\begin{array}{l}\text { 添at } \\
\text { ショョ }\end{array}$ & $\begin{array}{r}114.6 \\
8.82\end{array}$ & $\begin{array}{l}66.5 \\
51.2\end{array}$ & $\begin{array}{l}35.3 \\
0.960\end{array}$ & $\begin{array}{r}174.5 \\
-93.9\end{array}$ & $\begin{array}{l}14.64 \\
0.196\end{array}$ & $\begin{array}{r}-84.9 \\
5.9\end{array}$ & 974 \\
\hline & 赛測 & $\begin{array}{r}118.2 \\
8.91\end{array}$ & $\begin{array}{l}69.4 \\
47.4\end{array}$ & $\begin{array}{l}35.7 \\
0.957\end{array}$ & $\begin{array}{r}168.2 \\
-100.1\end{array}$ & $\begin{array}{l}14.36 \\
0.189\end{array}$ & $\begin{array}{r}-82.4 \\
2.9\end{array}$ & 975 \\
\hline
\end{tabular}
れにより求めたランプの各調波の電圧, 電流及びランプ電力

表 $9250,300 \mathrm{~W}$ 点灯回路のシミュレーション [200W 基準 $]$, 実測のそれぞれ

\begin{tabular}{|c|c|c|c|c|c|c|c|}
\hline 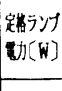 & & \multicolumn{2}{|c|}{ 楼 } & \multicolumn{2}{|c|}{ 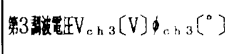 } & \multicolumn{2}{|c|}{ 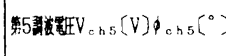 } \\
\hline \multirow{2}{*}{250} & シシュレーション & 118.5 & 137.7 & 48.0 & -4.2 & 14.22 & 99.9 \\
\hline & 実測 & 119.6 & 139.6 & 48.0 & 2.0 & 15.40 & 119.3 \\
\hline \multirow{2}{*}{300} & 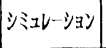 & 128.0 & 134.2 & 51.2 & -14.0 & 15.70 & 83.3 \\
\hline & 実测 & 129.6 & 134.1 & 48.0 & -15.6 & 16.00 & 89.2 \\
\hline & & \multicolumn{2}{|c|}{ 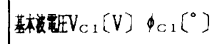 } & 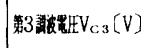 & $\varphi_{\mathrm{C} 3}\left({ }^{\circ}\right)$ & 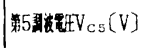 & $\phi_{\mathrm{C} 5}\left(0^{\circ}\right]$ \\
\hline \multirow{2}{*}{250} & |シンVーション & 312.8 & -38.2 & 14.09 & -180.0 & 1.50 & -74.5 \\
\hline & 実測 & 310. & -37.2 & 13.08 & -176.2 & 2.20 & -57.2 \\
\hline \multirow{2}{*}{300} & |シVーション| & 317. & -41.6 & 14.13 & 170.0 & 1.57 & -91.1 \\
\hline & 実测 & 310.8 & -42.9 & 12.36 & 167.2 & 1.89 & -88.6 \\
\hline
\end{tabular}
により求めたチョークコイルとコンデンサの各調波電圧

\begin{tabular}{|c|c|c|c|}
\hline \multicolumn{2}{|c|}{ 算出方法 } & A & $\mathrm{C}_{\mathrm{c}}$ \\
\hline \multicolumn{2}{|c|}{ 実測 } & 1. 886 & 2. $76 \times 10^{4}$ \\
\hline \multirow{2}{*}{ 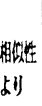 } & 200W 基泮 & 1. 910 & 2. $79 \times 10^{4}$ \\
\hline & 400W 基草 & 1. 780 & 2. $64 \times 10^{4}$ \\
\hline
\end{tabular}

表10 1000W 点灯回路のモデル定数の比較 
の各調波の電圧, 電流の成分及びチョークコイルとコンデンサの 各調波の電圧の成分を表12に示す。

表12を表4 と比較すると, ランプの基本波電圧, 電流は大きさ、 位相角共に実測値にほぼ等しい。表 12 第 3 , 第 5 調波の電圧, 電 流は表4のシミュレーションにより求めた結果に比較して実測值 との誤差が大きくなっている。チョークコイルとコンデンサの電 圧についても同様なことが言える。

$100 \mathrm{~W}$ 点灯回路を基準にして求めたモデル定数を用いた他の各 種定格点灯回路のシミュレーションによる結果についても同様な ことが言える(冗長になるので表は略する).

このことは図3に示すように $100 \mathrm{~W}$ 点灯回路のランプの電圧の 波形が電極の太さ等の違いから他の各種定格点灯回路のランプの 電圧波形と少し相似性に欠けることによるものと思われる。

表11 1000W 点灯回路のシミュレーション(400W 基準), 実測のそれぞれによ ク求めたチョークコイルとコンデンサの各調波電圧

\begin{tabular}{|c|c|c|c|c|c|c|}
\hline & 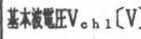 & ]$\phi_{a h 1}\left[0^{0}\right]$ & 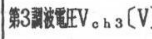 & ]$\phi_{\mathrm{ch} 3}\left[{ }^{\circ}\right]$ & 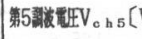 & V] $\phi_{\mathrm{eh} 5}\left({ }^{\circ}\right]$ \\
\hline シシュレーション & 145.1 & 136.1 & 46.8 & -11.9 & 15.08 & 83.6 \\
\hline \multirow[t]{2}{*}{ 実測 } & 146.8 & 137.3 & 47.2 & -10.4 & 15.26 & 94.5 \\
\hline & 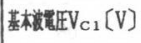 & $\phi_{C 1}\left[0^{\circ}\right]$ & 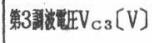 & $\phi_{\mathrm{C} 3}\left[{ }^{\circ}\right]$ & 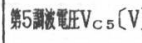 & 1] $\phi_{C 5}\left[{ }^{\circ}\right]$ \\
\hline シシュレーション & 334.3 & -39.3 & 12.0 & 172.3 & 1.39 & -90.6 \\
\hline 実測 & 331.6 & -40.8 & 11.3 & 170.5 & 1.56 & -86.2 \\
\hline
\end{tabular}

表12 200W 点灯回路のシミュレーション(100W 基準)により求めたランプの 各調波電圧, 電流及びチョークコイルとコンデンサの各調波電圧

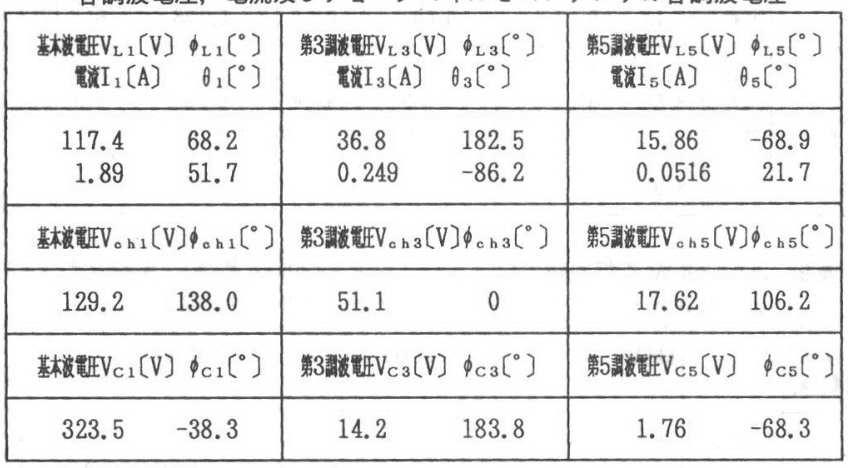

\section{2 入力端子電圧を变化させたときの高調波分析}

ランプ定格電力 $200 \mathrm{~W}$ 以上の点灯回路の定常状態では, 入力端 子電圧が 180 ～220V の範囲で, ラシプの電圧, 電流のそれぞれの 波形はほぼ相似になる。この相似性より、入力端子電圧が 180 ～ 220 $\mathrm{V}$ まで $10 \mathrm{~V}$ おきに変化したときの各種定格の点灯回路における 各素子の電圧, 電流を $200 \mathrm{~V}$ のきのランプのモデル定数を基準 にして求めることが可能である.

$200 \mathrm{~W}$ の進相形点灯回路の入力端子に $200 \mathrm{~V}, 60 \mathrm{~Hz}$ の定格電圧 を印加し, 安定状態に達した後, 入力端子電圧を 180 2 $20 \mathrm{~V}$ まで $10 \mathrm{~V}$ おきに変化したときのランプの電圧, 電流の波形を図5に示 す.

図 5 より、入力端子電圧が $200 \mathrm{~V}$ のときのランプの電圧, 電流波 形の最大值電圧 $160 \mathrm{~V}$ 及び最大值電流 $2.95 \mathrm{~A}$ に対する $180 、 190$ 、 210、220V のときのランプの電圧, 電流波形の最大值電圧及び最

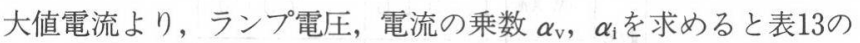
ようになる，ただし，定常状態では，ランプ電圧の大きさは入力
端子電圧の大きさに拘らずほぼ一定であるので $\alpha_{\mathrm{v}}=1$ となる. $\alpha_{\mathrm{v}}$ 、 $\alpha_{i}$ より求めた各入力端子電圧のときのモデル定数を同じく表 $13 に$ 示す.

各入力端子電圧のときの表 13 モデル定数を用いて, 入力端子 電圧 $200 \mathrm{~V}$ のとと同様にシミュレーションによリ求めた各入力 端子電圧のときのランプの各調波電圧, 電流の成分を求めること が可能である(呪長になるので表は略す).

ランプの各調波電圧に関して各入力端子電圧共に大きさはほぼ

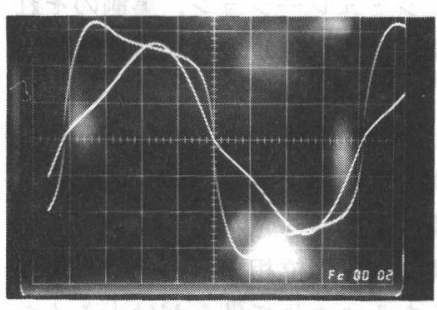

(a) $180 \mathrm{~V} 50 \mathrm{~V} / \mathrm{duv}$

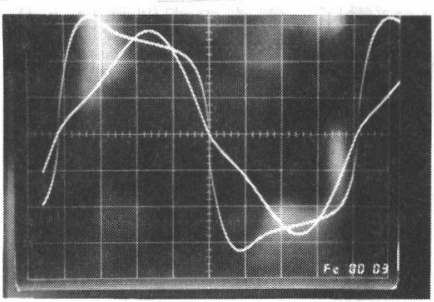

(b) $190 \mathrm{~V} 50 \mathrm{~V} / \mathrm{div}$ $1 \mathrm{~A} / \mathrm{div}$

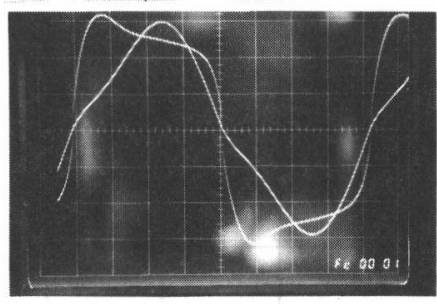

(c) $200 \mathrm{~V} 50 \mathrm{~V} / \mathrm{div}$

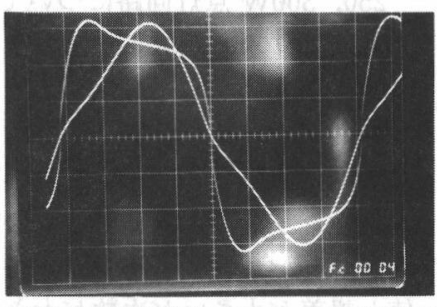

(d) $210 \mathrm{~V} 50 \mathrm{~V} / \mathrm{div}$ $1 \mathrm{~A} / \mathrm{div}$

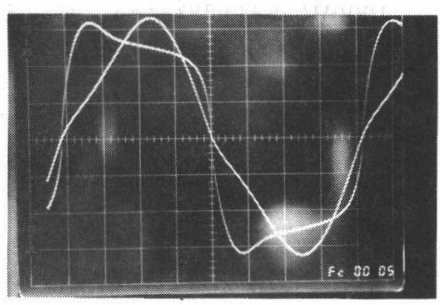
(e) $220 \mathrm{~V} \quad 50 \mathrm{~V} / \mathrm{div}$
$1 \mathrm{~A} / \mathrm{div}$
図 5200 進相形点灯回路のランプ電圧, 電流波形 $(\mathrm{L}=0.181 \mathrm{H}, \mathrm{C}=15.5 \mu \mathrm{F})$

表13 200W 進相形点灯回路の入力端子電圧を変化させたときのランプの電 流, 電圧の乗数とモデル定数 ( $200 \mathrm{~V}$ 基準)

\begin{tabular}{|c|c|c|c|c|}
\hline 劝灌子䨋王 [V & A & $\mathrm{C}_{\mathrm{c}}$ & $\alpha_{i}$ & $\alpha_{\mathrm{v}}$ \\
\hline 180 & 9. 19 & $13.69 \times 10^{4}$ & 0.898 & 1 \\
\hline 190 & 8. 64 & $12.87 \times 10^{4}$ & 0.956 & 1 \\
\hline 200 & 8. 26 & $12.30 \times 10^{4}$ & 1.000 & 1 \\
\hline 210 & 7. 87 & 11. $71 \times 10^{4}$ & 1.050 & 1 \\
\hline 220 & 7. 24 & $10.79 \times 10^{4}$ & 1.140 & 1 \\
\hline
\end{tabular}

等しく, 位相角は入力端子電圧が大きくなるにつれて僅かだけ大 きくなっている。

ランプの基本波電流に関しては入力端子電圧が大きくなるに伴 って大きくなっており，第3，第5調波電流に関しては僅かだけ大 きくなっている.位相角は各調波共に進みの方向に変化している. 入力端子電圧 $220 \mathrm{~V}$ のきのランプの各調波電圧, 電流の成分及 
びランプ電力についてシミュレーションにより求めた值及び実測 により求めたそれらを表14に示す。シミュレーションにより求め た各調波電圧, 電流の大きさ、ランプ電力はそれぞれほぼ実測值 に等しい。即ち，各調波電圧，電流の大きさ及びランプ電力に関 してはシミュレーションによる算出結果の精度が高いことを示し ている.

シミュレーションにより求めた各調波電圧, 電流の位相角はそ れぞれほぼ実測值との䛊差は小さいが次数が大きくなるにつれて 大きくなっている.

表14 入力端子電圧が220V のときのシミュレーション(200V 基準), 実測のそ れぞれにより求めたランプの各調波電圧, 電流及びランプ電力 $(200 \mathrm{~W}$ 進相形点灯回路)

\begin{tabular}{|c|c|c|c|c|c|c|c|}
\hline & 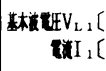 & $\begin{array}{l}\theta_{11}\left[^{0}\right] \\
\theta_{1}\left[0^{\circ}\right]\end{array}$ & 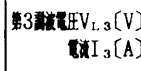 & $\begin{array}{c}\theta_{\mathrm{L} 3}\left[\left[^{\circ}\right]\right. \\
\theta_{3}\left[\left[^{\circ}\right]\right.\end{array}$ & 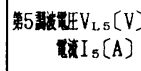 & $\begin{array}{l}\phi_{L 5}\left[\left[^{\circ}\right]\right. \\
\theta_{5}\left[{ }^{\circ}\right]\end{array}$ & $\begin{array}{l}5 y-1 \\
\mathrm{n} \rightarrow\end{array}$ \\
\hline タシュVーション & $\begin{array}{l}115.9 \\
2.10\end{array}$ & $\begin{array}{l}71.0 \\
55.5\end{array}$ & $\begin{array}{l}35.01 \\
0.237\end{array}$ & $\begin{array}{c}186.9 \\
-81.9\end{array}$ & $\begin{array}{l}14.04 \\
0.046\end{array}$ & $\begin{array}{r}-63.9 \\
26.7\end{array}$ & 235 \\
\hline 史湘 & $\begin{array}{l}116.8 \\
2.10\end{array}$ & $\begin{array}{l}71.9 \\
57.5\end{array}$ & $\begin{array}{l}34.08 \\
0.242\end{array}$ & $\begin{array}{l}189.4 \\
-73.0\end{array}$ & $\begin{array}{l}14.08 \\
0.045\end{array}$ & $\begin{array}{r}-49.2 \\
45.6\end{array}$ & 236 \\
\hline
\end{tabular}

入力端子電圧が $200,220 \mathrm{~V}$ のきの表 $4,14 \sigma$ 基本波電圧の大き さは互いにほぼ等しい，他の入力端子電圧のときも基本波電圧の 大きさは表 4,14 基本波電圧の大きさとほぼ等しい. 即ち, 春測,

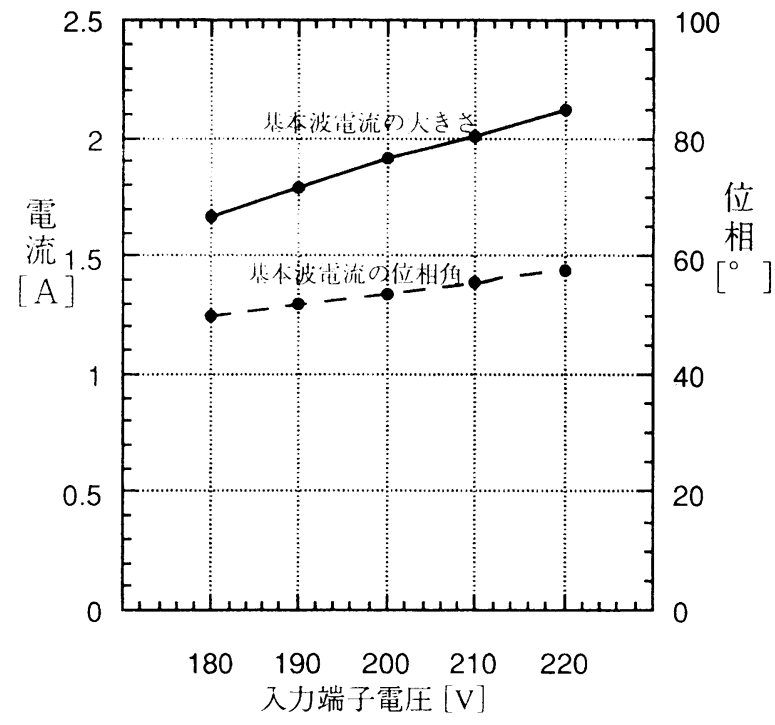

(a) ランプの基本波電流の大きさと位相角
シミュレーションのそれぞれの結果, 共に, 入力端子電圧が変わ つても基本波電压の大きさはほぼ等しいことを示している。

シミュレーションにより求めた各入力端子電圧のときのランプ の基本波電流，インピーダンスのそれぞれの大きさ及び位相角を 図6に示す. 図6によると入力端子電圧の増加に伴い, 水銀ランプ のインピーダンスの大きさは次第に小さくなっており，水銀ラン プが非線形性であることを示している。また，実測により求めた 各入力端子電圧のときのランプの基本波電流, インピーダンスの それぞれの大きさ及び位相角もほぼ同じような変化を示す(午長 になるので図は略す)。

入力端子電压 $220 \mathrm{~V} の$ ののシミュレーションより求めたチョ -ークコイル，コンデンサのそれぞれの各調波の電圧の成分及び契 測により求めたそれらを表15に示す。この場合もシミュレーショ ンにより求めた各調波電圧の大きさはそれぞれほぼ実測值に等し い。即ち, 各調波電压の大きさに関してはシミュレーションによ る算出結果の精度が高いことを示している。シミュレーションに より求めた各調波電圧の位相角はそれぞれ実測值と誤差が小さい が次数が大きくなるにつれて僅かだけ大きくなっている.

他の大力端子電圧についてもシミュレーションによりチョーク コイル，コンデンサの各調波の電圧，電流が求めることが可能で ある。

以上により，シミュレーションによる各素子の電圧，電流の高 調波分析結果の精度が高いことが分かったので以下，フリッカレ ス点灯回路のシミュレーションによる高調波分析に基づく特性に ついて述べる。

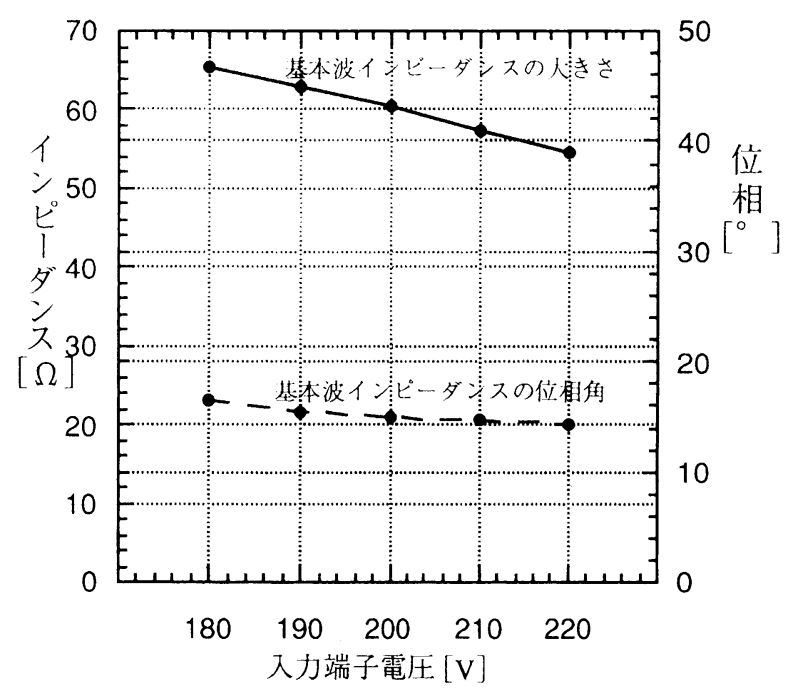

(b) ランプの基本波インピーダンスの大きさと位相角

図 6 ランプの基本波軋流, インピーダンスの変化

表15 入力端子電圧220V のときのシミュレーション，実測のそれぞれにより 求めたチョークコイルとコンデンサの各調波電圧 $(200 \mathrm{~W}$ 進相形点灯回 路)

\begin{tabular}{|c|c|c|c|c|c|}
\hline & 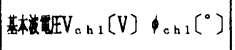 & 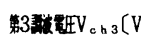 & V) $\phi_{\mathrm{cb} 3}\left({ }^{\circ}\right)$ & 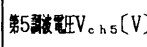 & $\phi_{\operatorname{chs} 5}\left({ }^{\circ}\right]$ \\
\hline ジュレーション & $143.8 \quad 142.0$ & 48.6 & 4.2 & 15.6 & 111.2 \\
\hline \multirow[t]{2}{*}{ 実测 } & $142.4 \quad 145.0$ & 47.60 & 13.1 & 16.68 & 133.7 \\
\hline & 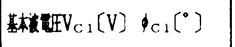 & 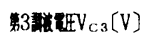 & $\left.\varphi_{\mathrm{c} 3} 0^{\circ}\right]$ & 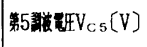 & $\operatorname{los}\left({ }^{\circ}\right)$ \\
\hline 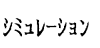 & $360.1-34.5$ & 13.52 & -171.9 & 1.57 & -63.3 \\
\hline 実測 & $354.00-32.7$ & 12.40 & -165.2 & 2.31 & -39.2 \\
\hline
\end{tabular}

\section{2 フリッカレス点灯回路の特性}

図 7 の $200 \mathrm{~W}$ のフリッカレス点灯回路の進相形点灯回路の L, C の組合せの值の変化による, 定常状態に達したときの特性変化に ついて述べる。ただし，入力端子電圧は $200 \mathrm{~V}, 60 \mathrm{~Hz}$ とする.

進相形点灯回路のランプ電圧, 電流をそれぞれ $120 \mathrm{~V}, 2.0 \mathrm{~A}(\mathrm{JIS}$

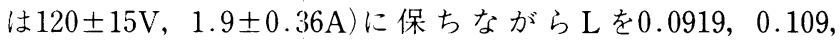
$0.125,0.139,0.1476,0.1668,0.186 \mathrm{H}$ と変化させるときの Cの 值は図 8 のようになる( $\mathrm{L}, \mathrm{C}$ の基本波に対するインピーダンス 


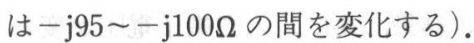

$\mathrm{L}$ の各值のときのランプ電圧, 電流の波形は図 9 のようになる.

$\mathrm{L}$ の各值のときのランプのモデル定数を 3.1 と同様にして求め ると表16のようになる。 また, 遅相形点灯回路の L は $0.18 \mathrm{H}$ を用 い, このランプ電圧, 電流の波形より求めたモデル定数の $\mathrm{A}=$ $8.015, \mathrm{C}_{\mathrm{C}}=11.089 \times 10^{4}$ を用いる。

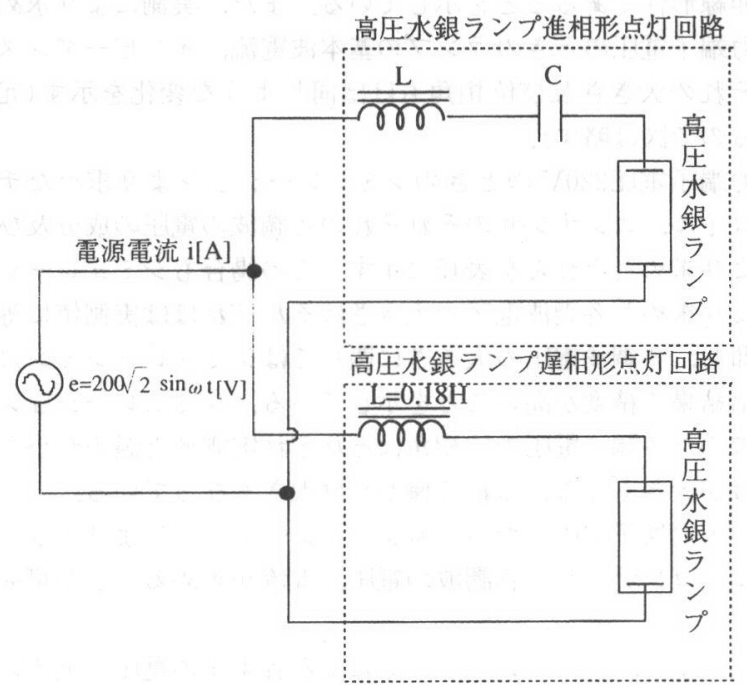

图 7 高圧水銀ランプ200W フリッカレス点灯回路

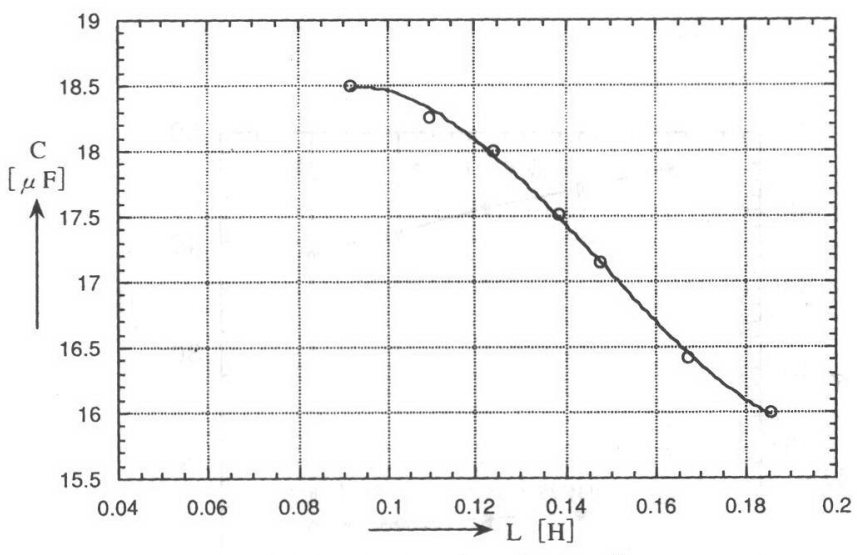

目 8 L, C の組み合わせの値

$\mathrm{L}, \mathrm{C}$ の組合せの值の変化に対するランプの基本波, 第 3 , 第 5 調 波電圧, 電流の大きさの変化を図10に示す. Lの増加に対してラン プの基本波電圧, 電流はほぼ一定の大きさを保っているが, L の増 加に伴って第3，第5調波電圧は僅かだけ増加の傾向を示す．しか L，L，Cの組合せの第3、第5調波インピーダンスが大きくなるた め第3電流は小さくなり, 第 5 調波電流はほぼ一定の大きさを示す.

$\mathrm{L}, \mathrm{C}$ の組合せの值の変化に対するランプの電力, 電流のひずみ 率, 波高率を図11に示す. L の増加に対してランプの電力はほぼ一 定值を示すが，ランプ電流のひずみ率は第 3 , 第 5 調波電流が減少 するので小さくなる。一方，ランプの寿命に関係するランプ電流 の波高率は L が大きくなるにつれて小さくなる。

$\mathrm{L}, \mathrm{C}$ の組合せの值の変化に対する電源の基本波，第3、第5調波 電流の大きさの変化, 力率及び電源電流のUずみ率を図 12 に示す。 Lの増加に対してフリッカレス点灯回路の電源の基本波電流の大 きさはほぼ一定であるが，第 $3 ，$ 第 5 調波電流が小さくなるので， 電源電流のUずみ率は小さくなる。また，このために力率は少し
づつ良くなるが $\mathrm{L}=0.186 \mathrm{H}$ のとぎも電源電流のひずみ率が進 相形、遅相形のそれぞれのランプ電流のUずみ率より大きく 16.5 \%であるために $100 \%$ にはならな.電源電流のUずみ率が $16.5 \%$ と大きいのは電源の第3調波電流が進相形,遅相形のそれぞれの第

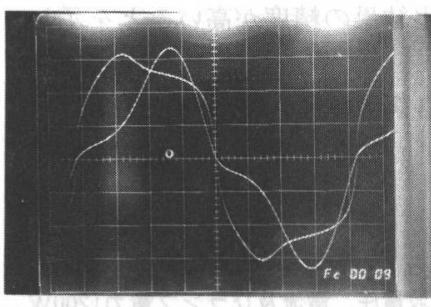

(a) $\mathrm{L}=0 . \mathrm{n} 919[\mathrm{H}], \mathrm{C}=18.5[\mathrm{AH}]$

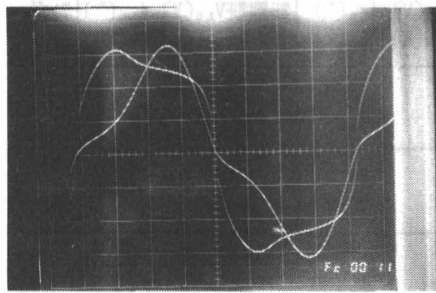

(b) $L=0.109(\mathrm{H}), \mathrm{C}=18.4[\mathrm{kP})$

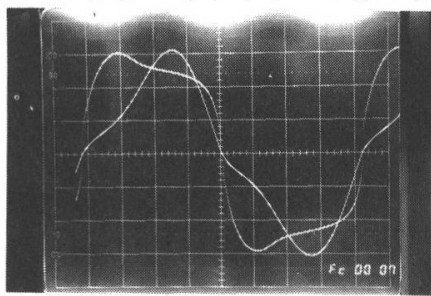

(c) $\mathrm{L}=0.125(\mathrm{H}), \mathrm{C}=18.0[\mu \mathrm{H})$

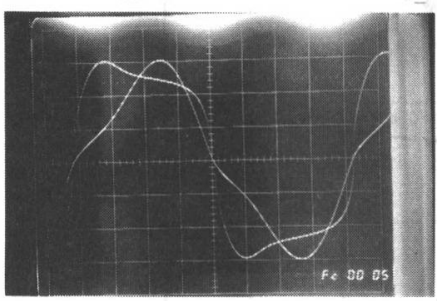

(d) $\mathrm{L}=0.139(\mathrm{II}), \mathrm{C}=17.5(\mathrm{\mu F})$

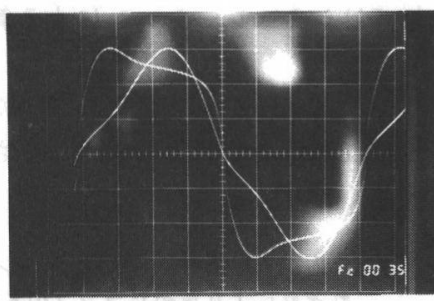

(e) $L=0.1476(\mathrm{H}), C=17,0[\mu \mathrm{F}]$

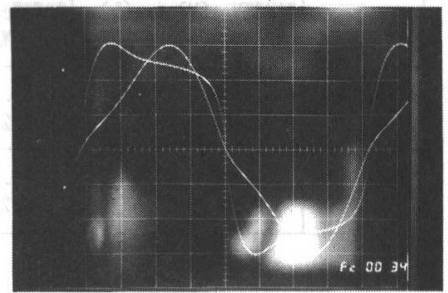

(f) $\mathrm{L}=0.1668[\mathrm{H}], \mathrm{C}=16.4[\mathrm{AF}]$

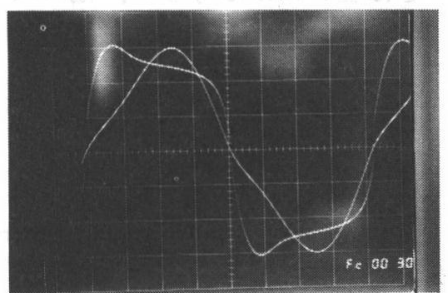

(g) $\mathrm{L}=0.186[\mathrm{H}], \mathrm{C}=16.0[\beta \mathrm{F}]$
図 9 L，C の組合わせのときのランプの電圧, 電流波形

表16 各 $\mathrm{L}, \mathrm{C}$ のときのモデル定数

\begin{tabular}{|l|c|c|}
\hline \multirow{2}{*}{$\begin{array}{l}\text { L、 } \\
\text { の值 } \\
{[\mathrm{H} \backslash[\mu \mathrm{F}]}\end{array}$} & \multicolumn{2}{|c|}{ モデル定数 } \\
\cline { 2 - 3 } & $\mathrm{A}$ & $\mathrm{C}_{\mathrm{C}}$ \\
\hline $0.0919 、 18.5$ & 9.3518 & $14.5 \times 10^{4}$ \\
\hline $0.109 、 18.4$ & 8.5885 & $13.2 \times 10^{4}$ \\
\hline $0.125 、 18.0$ & 10.623 & $16.4 \times 10^{4}$ \\
\hline $0.139 、 17.5$ & 9.5387 & $14.7 \times 10^{4}$ \\
\hline $0.1476 、 17.0$ & 7.6107 & $11.0 \times 10^{4}$ \\
\hline $0.1668 、 16.4$ & 8.4931 & $12.3 \times 10^{4}$ \\
\hline $0.1860 、 16.0$ & 8.9558 & $13.4 \times 10^{4}$ \\
\hline
\end{tabular}




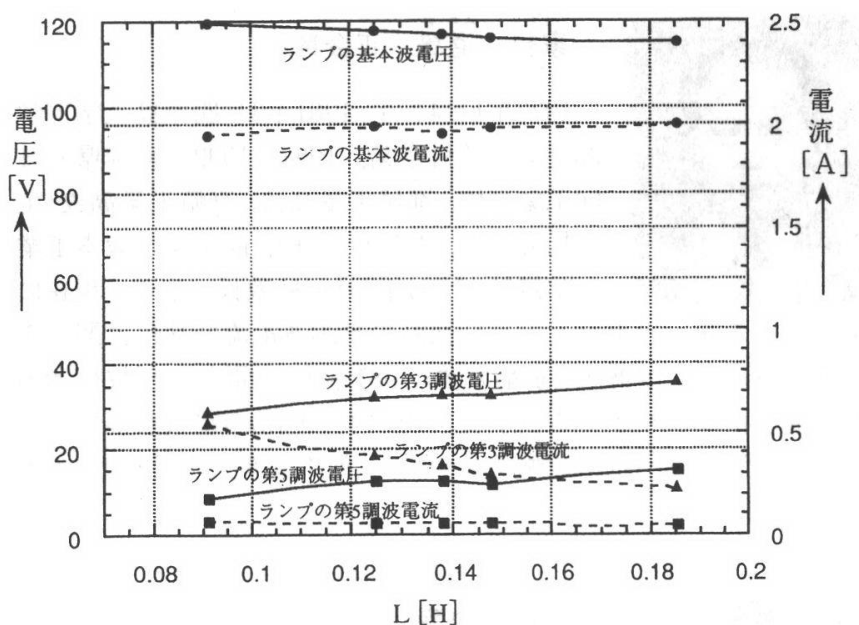

目10 L, C の組合わせの変化（ただし，Lで示す）に対するランプの基本波, 第3, 第5調波電圧, 電流

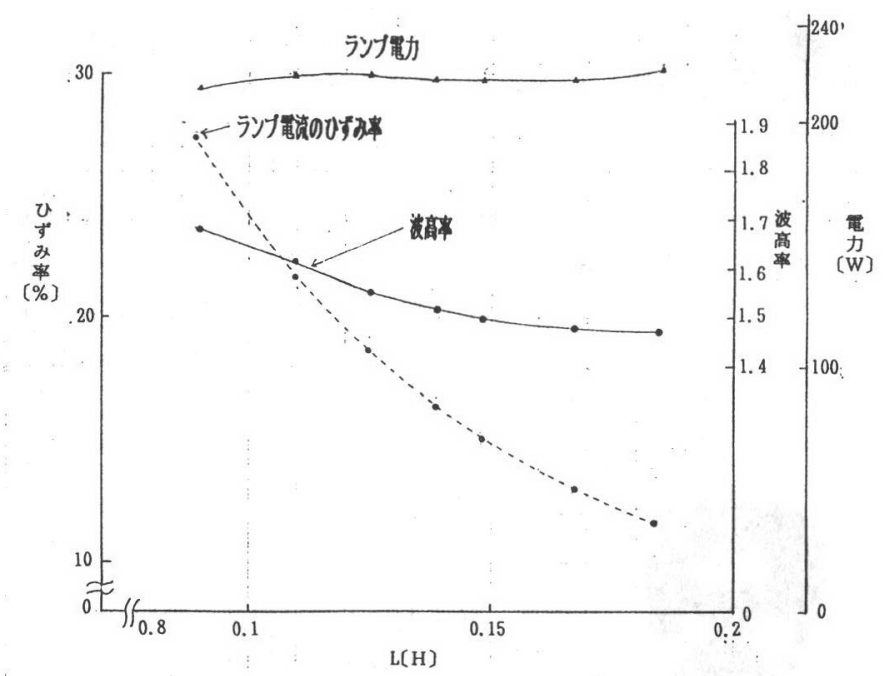

図11 L，C の組合わせの変化(ただし，Lで示す)に対するランプの電流のひ ずみ率, 波高率及びランプ電力

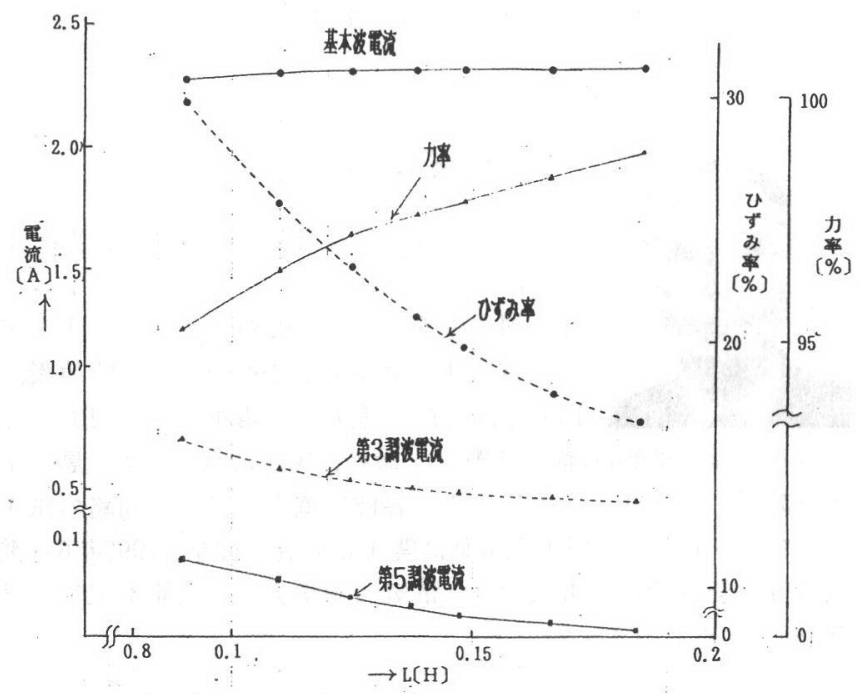

図12 L, C の組合わせの変化(ただし, L で示す) に対するフリッカレス点灯 回路の電源の基本波, 第3, 第5調波と電源電流のひずみ率, 力率
3調波電流より大きくなるためである。

$\mathrm{L}=0.186 \mathrm{H}, \mathrm{C}=16.0 \mu \mathrm{F}$ の進相形点灯回路, $\mathrm{L}=0.18 \mathrm{H}$ の遅相形 点灯回路を用いた $200 \mathrm{~W}$ フリッカレス点灯回路の電源電圧, 電流 の実測及びシミュレーションのそれぞれより求めた波形を図13に 示す. さらに, 同じ点灯回路の各端子の実測及びシミュレーショ ンのそれぞれより求めた各調波電流の成分を表17に示す。

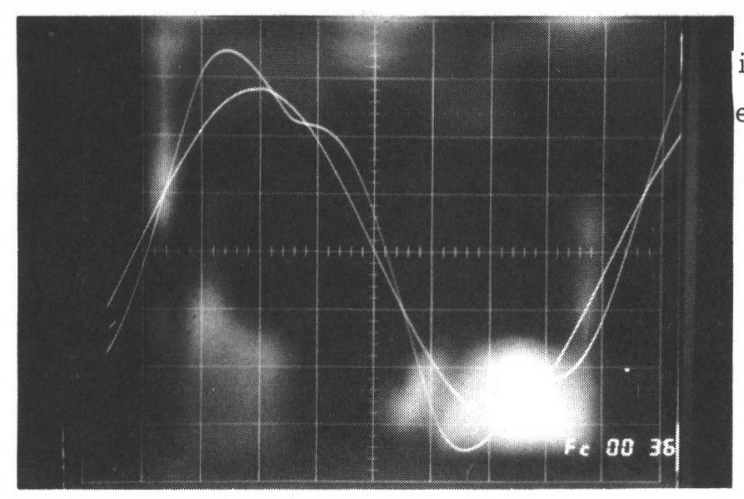

$\mathrm{i}: 1 \mathrm{~A} / \mathrm{div}$ :50V/div

(a) 実測

図13200W フリッカレス点灯回路の電源電圧, 電流波形

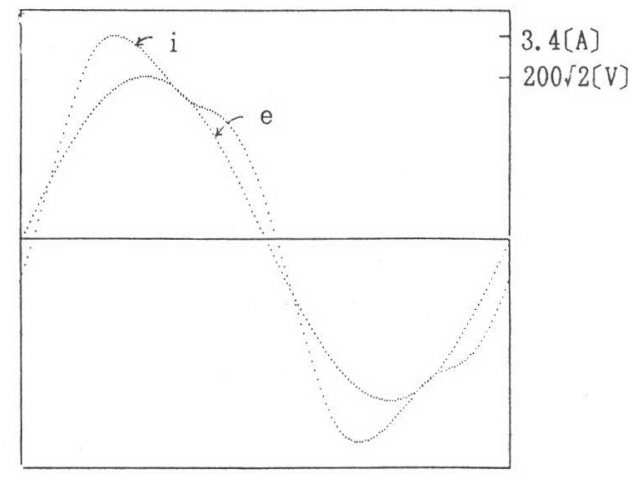

(b) シミュレーション

表17 シミュレーション, 実測のそれぞれにより求めたフリッカレス点灯回路 の各端子電流 (200W フリッカレス)

\begin{tabular}{|c|c|c|c|c|c|c|c|}
\hline & & 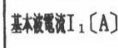 & $\theta_{1}\left[^{\circ}\right]$ & 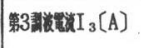 & $\theta_{3}\left({ }^{\circ}\right)$ & 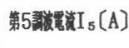 & ] $\theta_{5}\left(0^{\circ}\right]$ \\
\hline シシロレーション & 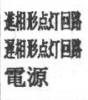 & $\begin{array}{l}2.02 \\
2.01 \\
2.33\end{array}$ & $\begin{array}{l}52.1 \\
-57.0 \\
-2.5\end{array}$ & $\begin{array}{l}0.232 \\
0.173 \\
0.392\end{array}$ & $\begin{array}{l}-89.5 \\
-64.3 \\
-78.9\end{array}$ & $\begin{array}{l}0.0480 \\
0.0428 \\
0.0167\end{array}$ & $\begin{array}{r}14.6 \\
174.5 \\
76.6\end{array}$ \\
\hline 実測 & 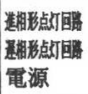 & $\begin{array}{l}2.02 \\
2.05 \\
2.39\end{array}$ & $\begin{array}{l}52.9 \\
-54.7 \\
-1.4\end{array}$ & $\begin{array}{l}0.230 \\
0.159 \\
0.369\end{array}$ & $\begin{array}{l}-86.6 \\
-54.1 \\
-73.2\end{array}$ & $\begin{array}{l}0.0489 \\
0.0436 \\
0.0147\end{array}$ & $\begin{array}{r}23.0 \\
183.9 \\
113.0\end{array}$ \\
\hline
\end{tabular}

\section{4. まとめ}

筆者等は高圧水銀ランプの等価コンダクタンスのモデル定数を ランプの電圧, 電流波形より求め, シミュレーションにより点灯 回路の安定点灯時の各素子の電圧、電流の高調波分析を行なった。 また, 高圧水銀ランプ各種定格点灯回路のランプの電圧, 電流波 形のそれぞれの相似性に着目した。ほぼ相似性が保たれていると き, ある一種の定格のモデル定数より他の定格のモデル定数が求 められ, シミュレーションにより点灯回路の各素子の電圧, 電流 の高調波分析が簡単にできることを示した. 同じく, シミュレー ションによりフリッカレス点灯回路の進相形点灯回路の L, Cの 組合わせの変化に対する特性について示した。本研究の結果を要 
約すると次のとおりである。

(1) シミュレーションによる点灯回路の各素子の電圧, 電流の高 調波分析結果は実測值との誤差が小さい.

(2) ランプの電圧，電流波形がそれぞれほぼ相似であるとき，あ る一種の定格のモデル定数より他の定格のモデル定数が簡単に 求められる。これらのモデル定数を用い, シミュレーションに より各種定格点灯回路の各素子の電圧, 電流を高調波分析した 結果は実測值との誤差が小さい.

（3）入力端子に $200 \mathrm{~V}$ の定格電圧を印加し定常状態に達した後, 入力端子電圧を $180 \sim 220 \mathrm{~V}$ まで変化したとき， $200 \mathrm{~V}$ のきの モデル定数を基準にして他の入力端子電圧のときのモデル定数 を簡単に求められる.シミュレーションにより, 各素子の電压、 電流を高調波分析した結果は実測值との誤差が小さい。

（4）シミュレーション，実測のそれぞれの結果，共に，入力端子 電圧の増加にかかわらず，ランプの基本波電圧はほぼ一定であ る.

（5）シミュレーション，実測のそれぞれの結果，共に，入力端子 電圧の増加につれ, 水銀ランプの基本波インピーダンスは次第 に小さくなっている.

(6) フリッカレス点灯回路の進相形点灯回路の L が小さくなる と, 波高率が大きくなる.Lが大きくなると電源電流のひずみ率 は小さくなり，力率も良くなる，しかし，電源電流のUずみ率 がランプ電流のそれより大きく $16.5 \%$ であるため力率は $100 \%$ にならない.

最後にランプの電圧, 電流の相似性による各種定格の等価コン ダクタンスのモデル定数算出法のご教示を賜った京都大学板谷良 平名誉教授に根心より謝意を表する。また，実験と資料の整理に 協力された本学の大学院生藤本直樹, 松田吉輝君に謝意を表する。

\section{参 考 文 献}

(1) H. Strauch.: Theorie der Schitungen für Gasentladungslampen III, Archiv fur Electrotechnik. Heft 9 pp. 561 572 (1939)

(2) 青池, 野村: 放電灯進相形点灯回路の理論解析(1), 照明学会誌第 58卷5号 pp. 206 214（昭 49）

(3) 栘見, 坊：水銀ランプ点灯回路のシュミレーションによる解析, 照明学会誌第59卷5号 pp.194 202（昭50)

(4) E. L. Laskowski: A Model of a Mercury Arc Lamp's Terminal V-I Behavior, IEEE Transaction on Industory Applications. Vol. 1A-17, No.4, July/August pp.418 426 (1981) （受付日1993年12月 6 日/採録日 1994 年 6 月 9 日)

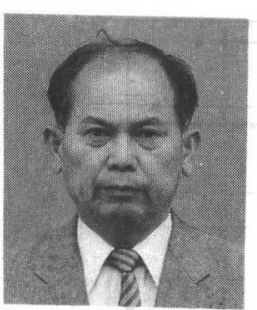

\section{家村道雄（正会員）}

1973年1月4日生. 1961年3月鹿児島大学工学 部電気工学科卒業. 1964 1992年宮崎県立日 向工業高校, 都城工業高校, 宮崎工業高校 (生 徒指導主事, 電気科主任). 同年 4 月熊本工業 大学講師, 1994年4月同助教授となり, 現在に 至る. この間, 放電ランプ点灯回路の高調波電流低減化に関する 研究に従事. 工学博士 (京都大学) 1981年第1種電気主任技術者国 家試験合格によりオーム奨学賞, 1992年6月第3回電気設備学会賞 受賞. 電気学会, 電気設備学会会員. (熊本工業大学 $=860$ 熊本市 池田 $4-22-1$ )

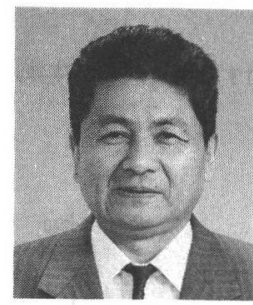

\section{田中 政幸（非会員）}

1939年1月15日生. 1966年3月九州工業大学 工学部第2部電気工学科卒業。1966年4月北九 州工業高等専門学校電気工学科文部教官助 手. 1970年4月同講師, 1974年4月同助教授, 1979年5月文部省内地研究員として, 京都大学 工学電気工学第2学科木嶋研究室 (木嶋昭教授) に非線形振動現象 の基礎的研究で国内留学，1985年4月同教授，1988年4月～1994年 3月 電気工学科主任兼任. 1993年10月～現在 北九州工業高等専 門学校専攻科設立準備委員兼任, この間, 電気回路振動現象の発 生と挙動に関する研究, 非線形回路の解と精密化と安定性に関す る研究に従事. 工学博士 (京都大学). 電気学会会員. (北九州高 等専門学校 $\mathbf{T} 803$ 北九州市小倉南区志井 5 丁目 $20 \sim 1$ )

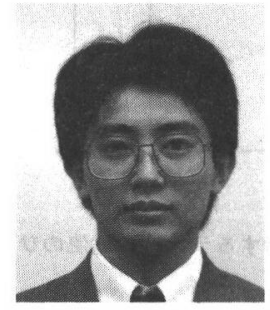

\section{埋錐阷明 (非会員)}

1963年10月17日生. 1986年 宮崎大学工学部電気工学科卒業 1986年 新日本製鐵侏)電気計装設計部勤務, 電子制御機器の開発に従事. 1991年 宮崎県 公立学校教諭に採用, 宮崎県立宮崎工業高等 学校電気科勤務, 放電ランプ点灯回路の高調波電流低減化の研究 に従事。電気設備学会会員. (宮崎工業高校= 880 宮崎市天満町 9 $\sim 1$ )

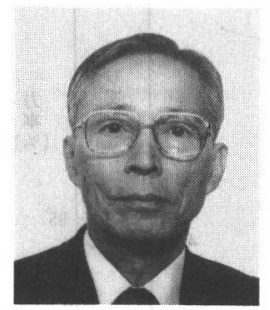

$$
\text { 山ロ施 純一 (専門会員) }
$$

1925年12月 22 日生. 1948 年 3 月鹿児島県立工 業専門学校電気科卒業. 同年 8 月同助手, 同校 昇格国立移管により, 1958年5月鹿児島大学工 学部電気工学科講師, 1961年4月同助教授, 1984年同教授 (電力工学講座担当)。1991年3 月定年退職。同年 4 月熊本工業大学教授, 現在に至る。鹿児島大学 名誉教授. 工学博士. 主として, 各種放電ランプ点灯回路の試作 および, Uずみ波の発生と挙動に関する研究に従事. 1992年6月電 気設備学会賞受賞. 電気学会, 電気設備学会会員 (熊本工業大学 于860熊本市池田 $4-22-1$ ) 